\title{
Tertiary Meteoric Hydrothermal Systems and their Relation to Ore Deposition, Northwestern United States and Southern British Columbia
}

\author{
ROBERT E. CRISS \\ Department of Geology, University of California, Davis \\ ROBERT J. FLECK \\ U.S. Geological Survey, Menlo Park, California \\ Hugh P. TAYLOR, JR.
}

Division of Geological and Planetary Sciences, California Institute of Technology, Pasadena

\begin{abstract}
Tertiary meteoric hydrothermal systems have altered the rocks exposed over more than $5 \%$ of the land surface of the northwestern United States and southern British Columbia, including at least $25,000 \mathrm{~km}^{2}$ in Idaho. The systems typically involved convective circulation of fluid derived from ordinary meteoric groundwaters around crystallizing, calc-alkaline, epizonal plutons emplaced into coeval volcanic cover rocks. These individual systems had widely ranging "lifetimes" of $10^{3}$ to $10^{6}$ years and operated locally throughout the Cenozoic, although the most profound devolopment of such activity occurred during Eocene time. Individual systems varied in size from a few tens of square kilometers (Yankee Fork, Idaho) or less to several thousand square kilometers (Sawtooth and Castro ring zones, Idaho) Typically, regional propylitization aacompanied the fluid circulation, although the higher-lemperature alteration assemblages were developed locally, as were intense alteration effects (e.g., silicification, sericitization, etc.) near some veins and in mining districts. A significant amount, probably 25-50\%, of the mineral production and potential in the region is closely related to Tertiary meteoric hydrothermal systems. Oxygen and hydrogen isotopic data clearly demonstrate the close geologic association of meteoric hydrothermal systems amd mineralization in (1) the Paleocene, Cu-Zn-Pb-Mn Main Stage mineralization at Butte, Montana; (2) numerous Eocene epithermal deposits principally valued for $\mathrm{Au}$ and $\mathrm{Ag}$ but also including significant deposits of $\mathrm{Cu}, \mathrm{Pb}, \mathrm{Zn}, \mathrm{F}, \mathrm{Sb}$, etc., as at Republic, Washington, and in several mining districts in the Idaho batholith and the Challis volcanic field; (3) several Eocene skarn deposits valued for W (Ima, Idaho) and Cu (Mackay, Idaho); (4) important leadsilver vein and replacement deposits of Tertiary (Bluebell, British Columbia) and of probable Cretaceous and early Tertiary age (Wood River, Idaho); (5) several potentially economic Mo-, Be-, and U-bearing Eocene "porphyry" plutons; and (6) Miocene epithermal deposits, most prominently the $\mathrm{Au}$ and $\mathrm{Ag}$ bearing veins at Silver City and DeLamar, Idaho, the $\mathrm{Hg}$ deposits at the McDermitt caldera, Nevada and Oregon, and at Weiser, Idaho, and Au deposits in the Western Cascade Range and Lake County, Oregon. A close spatial association has been demonstrated between ore deposits and rocks having anomalous $\delta^{18} \mathrm{O}$ values and low $\delta \mathrm{D}$ values. The most important deposits are associated with relatively small (generally 5-300 $\mathrm{km}^{2}$ ) zones of low $\delta^{11} \mathrm{O}$ values, and they are particularly closely linked with zones of very steep ${ }^{110} \mathrm{O} /{ }^{16} \mathrm{O}$ gradients in the altered rocks. These associations hold much promise for the use of $\delta^{18} O$ and $\delta D$ contour maps in future exploration efforts.
\end{abstract}

\section{INTRODUCTION}

Oxygen and hydrogen isotopic ratios are the only intrinsic properties of $\mathrm{H}_{2} \mathrm{O}$ that are known to be both variable and easily measured; hence they provide the only unequivocal data on the origin of natural aqueous fluids [Craig et al., 1956]. Application of these principles proves that fluids derived from meteoric waters played a critical role in the formation of numerous ore deposits of the western United States. Prominent examples are the epithermal $\mathrm{Au}$ and $\mathrm{Ag}$ deposits of Nevada, such as Tonopah, Goldfield, and the Comstock Lode [Taylor, 1973, 1974a; O'Neil and Silberman, 1974], and several copper porphyry and vein deposits [Sheppard et al., 1969, 1971]. A particularly important example is the Main Stage mineralization of the zoned $\mathrm{Cu}-\mathrm{Zn}-\mathrm{Pb}-\mathrm{Mn}$ deposit at Butte, Montana [Garlick and Epstein, 1966; Sheppard and Taylor. 1974].

In the last two decades, so many $\delta^{\mathbf{1 8}} \mathrm{O}$ and $\delta \mathrm{D}$ determinations have been made of rocks from the northwestern United States and southem British Columbia that this area is now the best

Copyright 1991 by the American Geophysical Union

Paper number 91JB00640.

0148-0227/91/91JB-00640\$05.00 studied region of the world from the point of view of the distribution of oxygen and hydrogen isotopes (Figure 1) [Taylor, 1971; Sheppard and Taylor, 1974; Taylor and Magaritz, 1978; Criss and Taylor, 1983; Criss et al., 1982. 1984, 1985; Criss and Champion, 1984; Fleck and Criss, 1985; Magaritz and Taylor, 1976, 1986; Criss and Fleck, 1987]. Conclusions of these studies are (1) deep circulation of heated meteoric waters accompanied the emplacement of many igneous intrusions throughout this region, particularly the early Tertiary granitic plutons; (2) water-rock interactions occurred on a regional scale, typically producing propylitic mineral assemblages and significant alteration of the bulk chemical, physical, and isotopic properties of both the central intrusions and their surrounding country rocks; (3) meteoric hydrothermal alteration was especially prominent in many mining districts, along rift zones and major faults, and along ring fractures associated with caldera collapse.

This paper discusses existing stable isotope data in the northwestern United States and southem British Columbia and adds a limited amount of new data. A brief review of the geologic characteristics of meteoric hydrothermal systems and of the isotopic and petrographic effects associated with them is included to introduce basic concepts and to place the discussion of the ore deposits in proper context. 


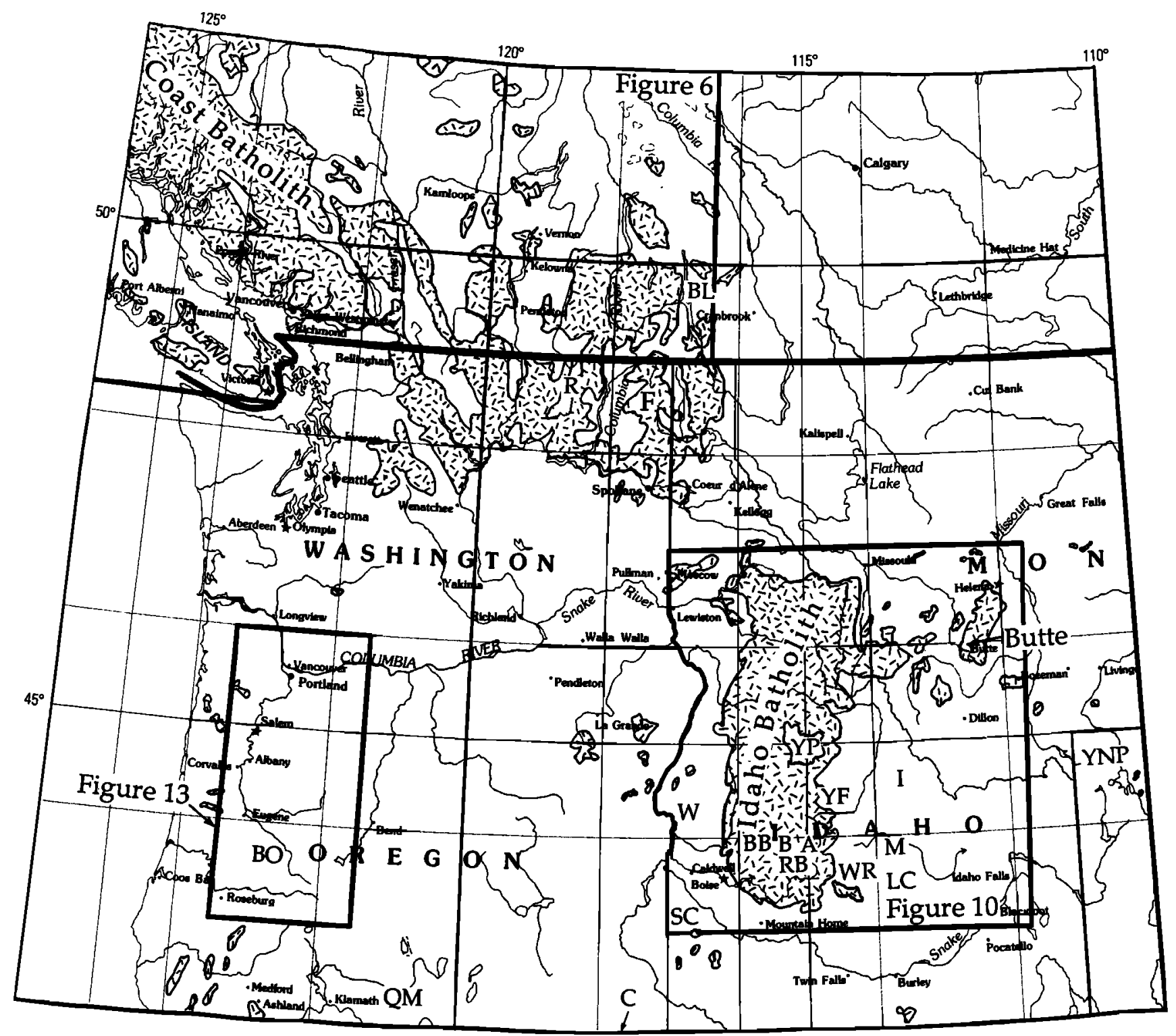

Fig. 1. Map of the northwestem Uniled States and southem British Columbia, showing major bodies of Mesozoic and Tertiary intrusive rock (pattem). Areas of Figures 6, 10, and 13 are indicated. Mining districts and other areas discussed in this report are as follows: Atlanta (A), Banner (B), Bluebell (BL), Boise Basin (BB), Bohemia (BO), Cordero (McDermit caldera; C), Flodelle Creek (F), Ima (I), Lava Creek (LC), Mackay (M), Quanz Mountain (QM), Republic (R), Rocky Bar (RB), Silver City (SC), Weiser (W), Wood River (WR), Yankee Fork (YF), Yellowstone National Park (YNP), and Yellow Pine (YP).

\section{CHARACTERISTICS OF METEORIC HYDROTHERMAL SYSTEMS}

\section{Geologic Relationships and Occurrence}

Meteoric hydrothermal systems occur in subaerial regions characterized by high heat flow, particularly where igneous plutons intrude permeable, water-saturated volcanic rocks near the Earth's surface [Taylor, 1971]. Convective flow, much of which is probably unicellular in nature [Criss and Hofmeister, 1991], is caused by buoyancy forces that arise from thermal expansion of the aqueous fluid, such that this hot fluid is displaced upward by the radially inward flow of cooler, more dense fluid toward the thermal anomaly (Figure 2). These phenomena are typically dominated by the boiling curve of water under hydrostatic pressure; however, some systems exhibit a surficial "acid-sulfate" zone that is probably related to steam condensation [White et al., 1971; White, 1973;
Larson and Taylor, 1987]. At deeper levels the flow regime is dominated by the near coincidence of a heat capacity maximum, thermal expansion maximum, and viscosity minimum of the aqueous fluid near its critical point [Norton, 1984].

In regions of meteoric hydrothermal activity in a continental setting, the associated magmatism typically displays silicic calc-alkaline chemistry. Such silicic magma chambers are commonly large and shallow, and the explosive character of these viscous magmas promotes fracturing and enhanced permeability [e.g., Smith and Shaw, 1973].

Meteoric hydrothermal systems vary greatly in size and in longevity. Relatively small systems $\left(<100 \mathrm{~km}^{2}\right.$ and $10^{3}$ to $10^{5}$ years) occur around small stocks and volcanic centers about $1-5 \mathrm{~km}$ in diameter, whereas much larger systems (thousands of square kilometers and several hundred thousand years duration) are associated with subvolcanic batholiths and 


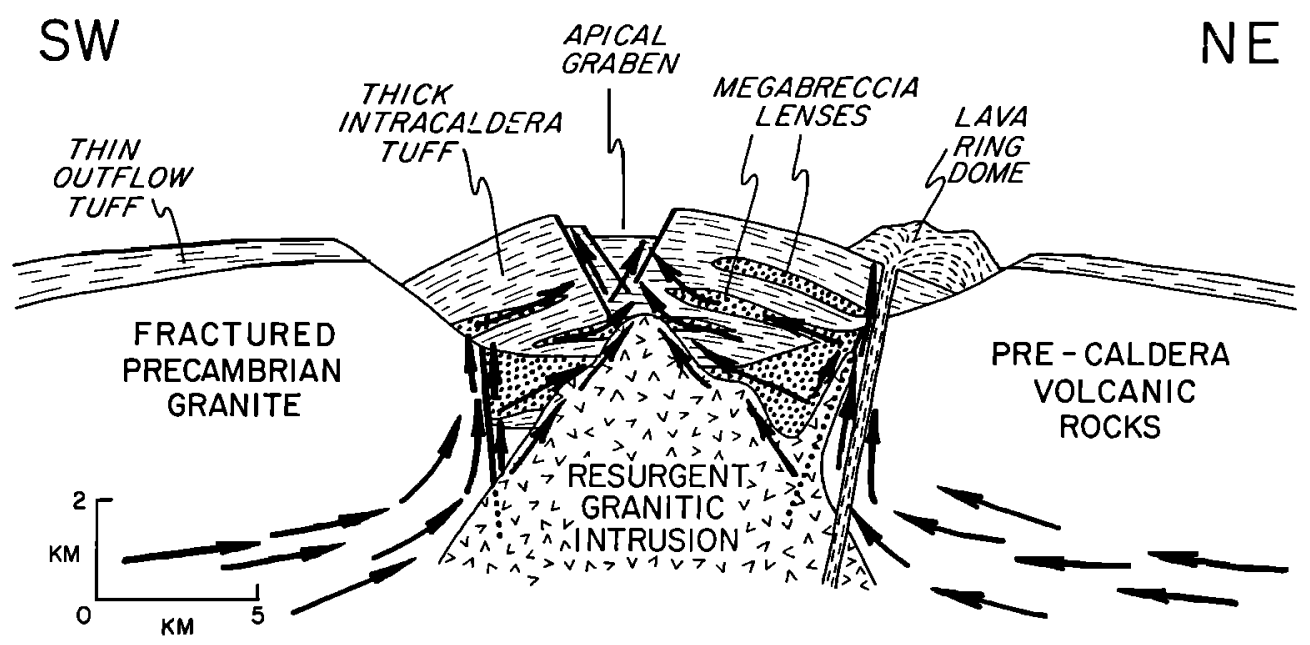

Fig. 2. Idealized geologic cross section of the Lake City, Colorado, caldera, showing the central resurgent intrusion and the generalized hydrothermal convective flow pattem (arrows) in the vicinity of the caldera at the time of its formation at about 23 Ma. Taken from Larson and Taylor [1986], modified after Lipman [1976]. The highest water-rock ratios and the greatest degree of hydrothermal exchange typically occur (1) along fractures, particularly along the major ring fracture of the caldera and (2) along the contact and just outside the central resurgent intrusion.

calderas. Truly giant systems $\left(>5,000 \mathrm{~km}^{2}\right.$ and $1-5$ m.y.) occur along major rift zones (e.g., Yellowstone Plateau) or where oceanic spreading centers impinge on continents (Salton Sea, California) or on islands such as Iceland [Criss and Taylor, 1986]. Fluid circulation to depths of $5-10 \mathrm{~km}$ or more is common in many of these environments [Taylor and Forester, 1979; Criss and Taylor, 1983, 1986].

The lifetime of a given hydrothermal system is obviously constrained by the total heat energy it contains. This energy is mainly that brought in by the magma, but it is important to note that in large, deep systems the waters that flow radially toward the magma body may already have been heated to 100 $200^{\circ} \mathrm{C}$ by the regional geothermal gradient, particularly in areas of high heat flow. Available geologic evidence [e.g., Silberman et al., 1979] and computer models [Norton and Knight, 1977] indicate that typical lifetimes of meteoric hydrothermal systems are about $10^{3}$ to $10^{6}$ years; the longer times are mainly correlated with the larger-sized plutons, but other factors (latent heat of crystallization, crystal/liquid ratio in the magma, etc.) also play a role. Permeability of the wall rocks and particularly of the crystallized intrusion is also a key and highly variable factor, because fluid flux is directly proportional to permeability (Darcy's law) and because the permeabilities of common geologic materials vary by a factor of more than $10^{13}$ ! The shape and even the orientation of the central intrusion may also be significant. The various factors that contribute to significant differences in the cooling, infiltration, and alteration histories of granitic and gabbroic intrusions are discussed and summarized by Taylor [1977, 1987] and Criss and Taylor [1986].

\section{Sources of Natural Hydrothermal Fluids}

The determination of the sources of the aqueous fluids in geothermal regions has been the subject of a long and active research effort; however, prior to the last few decades no unequivocal criteria were available to solve the question of fluid origin. It remained for Craig et al. [1956] to demonstrate, using oxygen and hydrogen isotope data, that the water discharged in most modern geothermal areas is dominantly
(>95\%) of surficial origin. The geothermal fluids typically have $\mathrm{D} / \mathrm{H}$ ratios identical to local meteoric waters, which vary from one geographic area to another in response to meteorological factors (Figure 3). On the other hand, the ${ }^{18} \mathrm{O} /{ }^{16} \mathrm{O}$ ratios of these fluids are higher than the local meteoric waters, a natural consequence of interaction and exchange between the hot fluids and the surrounding rocks. The latter constitute a giant reservoir of oxygen (but not of hydrogen) that is generally much richer in ${ }^{18} \mathrm{O}$ than the fluid. Figure 3 shows the isotopic compositions of typical geothermal waters and several types of calculated waters that have been inferred to exist in some fossil geothermal areas.

A complicating factor in the application of the isotope method is that the meteoric waters of most of the temperate regions of the Earth have $\mathrm{D} / \mathrm{H}$ ratios similar to those inferred for magmatic waters. If such waters undergo a significant ${ }^{18} \mathrm{O}$ shift, they may become isotopically indistinguishable from magmatic waters (Figure 3). Even more problematical are waters that undergo exchange with rocks under conditions of high temperatures and very low fluid/rock ratios. In such a case both the $\delta D$ and $\delta^{18} \mathrm{O}$ value of the fluid can become identical to magmatic waters, regardless of their initial composition [e.g., Campbell et al., 1984]. This can seriously complicate studies of ore deposits, particularly because both meteoric and magmatic hydrothermal fluids may act in concert to form many types of ores, for example porphyry copper deposits [Sheppard et al., 1969, 1971]. It is therefore important to study deposits in regions such as the northwestem United States and southern British Columbia where the meteoric waters are extremely depleted in both $D$ and ${ }^{18} \mathrm{O}$. In such areas, even highly evolved meteoric waters can still be identified by their D/H signatures.

Because of their surface meteoric origin from river water, lake water, and groundwater, meteoric hydrothermal fluids are typically dilute, containing only a few weight percent of dissolved constituents. Ellis and Mahon [1964] demonstrated that the dissolved constituents in most modern geothermal fluids can be accounted for by reactions with ordinary wall rocks; a magmatic source is therefore not required. Nevertheless, this does not preclude the possibility that 


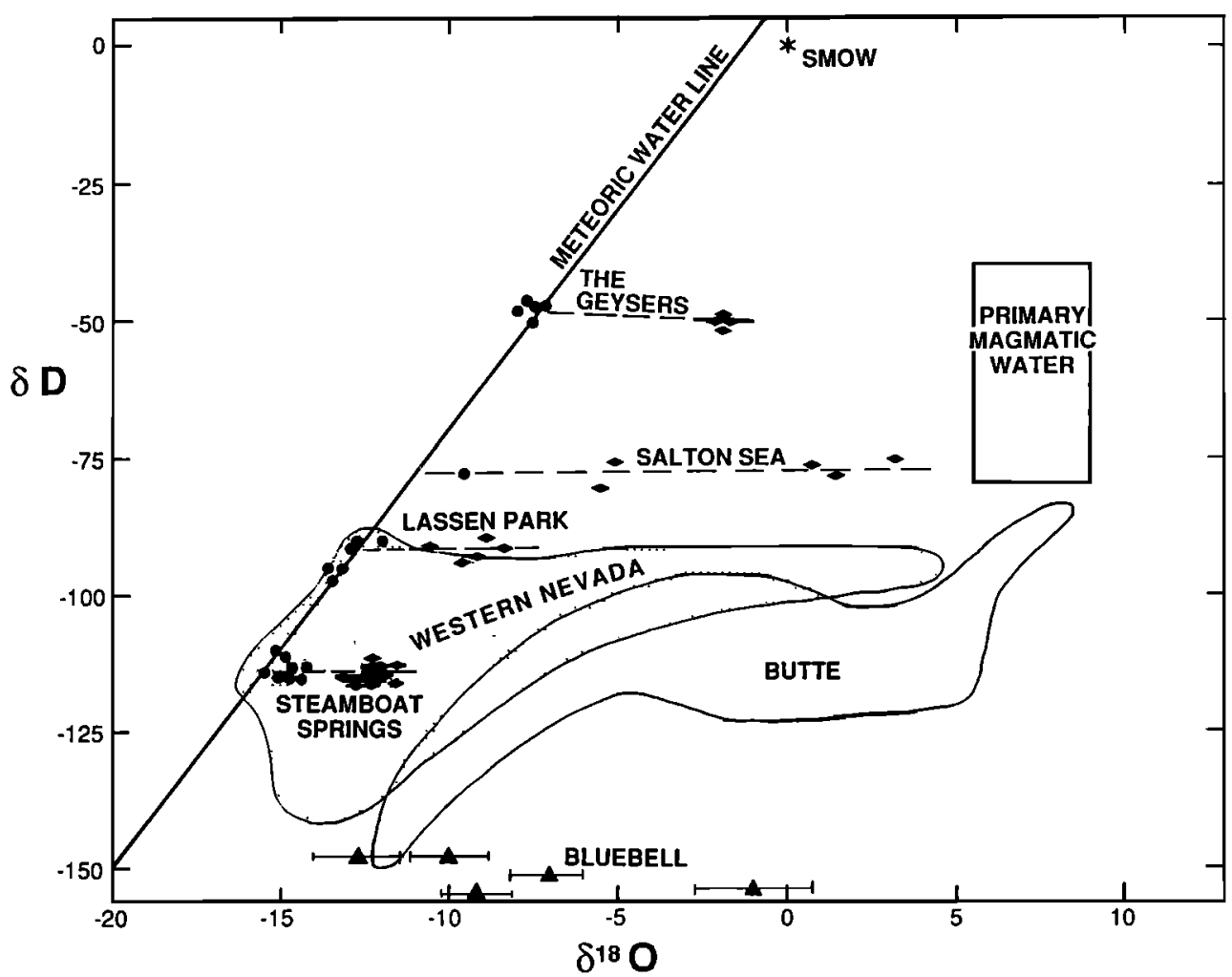

Fig. 3. Graph of $\delta \mathrm{D}$ and $\delta^{18} \mathrm{O}$ values of aqueous fluids of various origins, modified after Taylor [1974a] and Craig [1963]. Cool meteoric waters from several localities in the westem United States (solid dots) conform to the meteoric water line (MWL) of Craig [1961l, and vary from one area to another in accord with meteorological factors. Such waters are almost invariably depleted in ${ }^{8} \mathrm{O}$ and $\mathrm{D}$ relative to standard mean ocean water (SMOW), with the depletion becoming increasingly pronounced as one progresses into increasingly colder, more interior, and higher-latitude regions. However, near-neutral, chloride-type geothermal waters (solid diamonds) at The Geysers, Salton Sea, and Lassen Park, California, at Steamboat Springs, Nevada, and at many other geothermal areas of the world (not shown) have identical $\delta \mathrm{D}$ values but higher $\delta^{18} \mathrm{O}$ values than those of the local meteoric waters. This phenomenon, termed the " $18 \mathrm{O}$ shift" (dashed horizontal lines), was caused by interactions of the heated fluids with rocks, which are generally much richer in ${ }^{18} \mathrm{O}$. The measured and calculated $\delta \mathrm{D}$ and $\delta^{18} \mathrm{O}$ values of Tertiary hydrothermal fluids from several epithermal ore deposits in westem Nevada [O'Neil and Silberman, 1974], from the Main Stage mineralization at Butue, Montana [Sheppard and Taylor, 1974], and from the Bluebell mine, British Columbia [Ohmoto and Rye, 1970] seem to have a meteoric origin but clearly exhibit the phenomenon of ${ }^{18} \mathrm{O}$ shift seen in the modem, chloride-type geothermal waters. Calculated values of primary magmatic waters (box) are distinct from all of the above.

significant amounts of magmatically derived sulfur, metal, and other components may be present in the fluids.

\section{Isotopic Effects of Fluid-Rock Exchange}

The isotopic shifts that occur in hydrothermal fluids are necessarily related, by material balance, to complementary changes in the rocks. Because the $\delta D$ and $\delta^{18} \mathrm{O}$ values of most meteoric waters are generally lower than those of ordinary rocks, the $\delta \mathrm{D}$ and $\delta^{18} \mathrm{O}$ values of the rocks that interact with meteoric hydrothermal fluids commonly undergo substantial lowering. However, under the lowest-temperature conditions $\left(<100^{\circ} \mathrm{C}\right)$, the $\delta^{18} \mathrm{O}$ values of the rocks may in certain cases increase, particularly at low latitudes or on islands where the meteoric waters are not strongly depleted in $\mathrm{D}$ and ${ }^{18} \mathrm{O}$. This is because mineral- $\mathrm{H}_{2} \mathrm{O}$ equilibrium ${ }^{18} \mathrm{O} /{ }^{16} \mathrm{O}$ fractionation factors are very large at low temperatures.

In modern geothermal systems the fluid can be sampled and analyzed directly and interpreted as discussed above. Analogous information can be derived from zones of ancient hydrothermal activity by (1) direct $\mathrm{D} / \mathrm{H}$ analysis of fluid trapped in inclusions in silicates or oxides, or combined ${ }^{18} \mathrm{O} /{ }^{16} \mathrm{O}$ and $\mathrm{D} / \mathrm{H}$ analysis of fluid inclusions in sulfides or other nonoxygen bearing minerals; (2) isotopic analysis of vein materials that precipitated from the fluid, or by (3) isotopic analysis of preexisting but highly altered rock materials that underwent complete equilibration with the fluid. The latter two methods require knowledge of the fluid-mineral isotopic fractionation factors; which in tum depend on the temperature of exchange.

In detail, the response of isotopic systems to fluid-rock exchange depends on the initial isotopic compositions of the fluid $\left(\delta_{i} W\right)$ and rock $\left(\delta_{i} R\right)$, on the temperature as reflected by the water-rock fractionation factor $(\Delta)$, on the relative proportions of oxygen or hydrogen in the fluid and rock involved in the exchange (the material-balance water/rock ratio, abbreviated $W / R$ ), on the degree of approach to isotopic equilibrium, and on various boundary conditions appropriate to the local situation. In the most simplified and straightforward case, where isotopic equilibrium is attained in a closed system, the conservation relation is [Taylor, 1977]

$$
\left(\frac{\mathrm{W}}{\mathrm{R}}\right)_{\text {closed }}=\frac{\delta_{\mathrm{f}} \mathrm{R}-\delta_{\mathrm{i}} \mathrm{R}}{\delta_{\mathrm{i}} \mathrm{W}-\left(\delta_{\mathrm{f}} \mathrm{R}-\Delta\right)}
$$

where $\delta_{f} R$ is the final isotopic composition of the rock, and 
the difference $\left(\delta_{f} R-\Delta\right)$ is equal to the final isotopic composition of the fluid. This material balance $W / R$ ratio is thus simply equal to the ratio of isotopic shifts observed in the fluid and rock, analogous to the "lever rule". Under open system (i.e., "one-pass" system) conditions, where individual tiny packets of fluid are allowed to equilibrate with a large volume of rock and then are discarded, followed by successive increments of fluid that interact under the same conditions, the relation is [Taylor, 1977]

$$
\left(\frac{\mathrm{W}}{\mathrm{R}}\right)_{\text {open }}=\ln \left[\left(\frac{\mathrm{W}}{\mathrm{R}}\right)_{\text {closed }}+1\right]
$$

Note that the $W / R$ ratios depicted by these simplified equations are molar ratios that have very different meanings for hydrogen and oxygen, because the hydrogen content of rocks is small $(<5 \mathrm{wt} \%)$ relative to the oxygen content $(\sim 46$ wt \%). Accordingly, a relatively small $W / R$ ratio by weight would also be a small $W / R$ ratio in terms of molar oxygen, insufficient to cause a significant shift in the $\delta^{18} \mathrm{O}$ ratio of the rock; yet the same small $W / R$ weight ratio would be very large in terms of molar hydrogen, and any fluid/rock exchange under such conditions always results in a significant $\delta D$ shift of the rock [Taylor, 1977]. This explains why the $\delta D$ values of biotites in the altered granitoids of the Idaho batholith surrounding the large Eocene epizonal plutons change dramatically, from primary igneous values of about -70 to completely exchanged values of about -150 , well outboard of the central regions where the $\delta^{18} \mathrm{O}$ values of coexisting feldspar are measurably affected (Figure 4). Only by continued fluid-rock alteration at high, cumulative $W / R$ ratios will the feldspar $\delta^{18} \mathrm{O}$ values decrease, and long before this stage the $\delta \mathrm{D}$ values of the totally equilibrated biotites (or chloritized biotites) will already have attained a constant value (Figure 4).

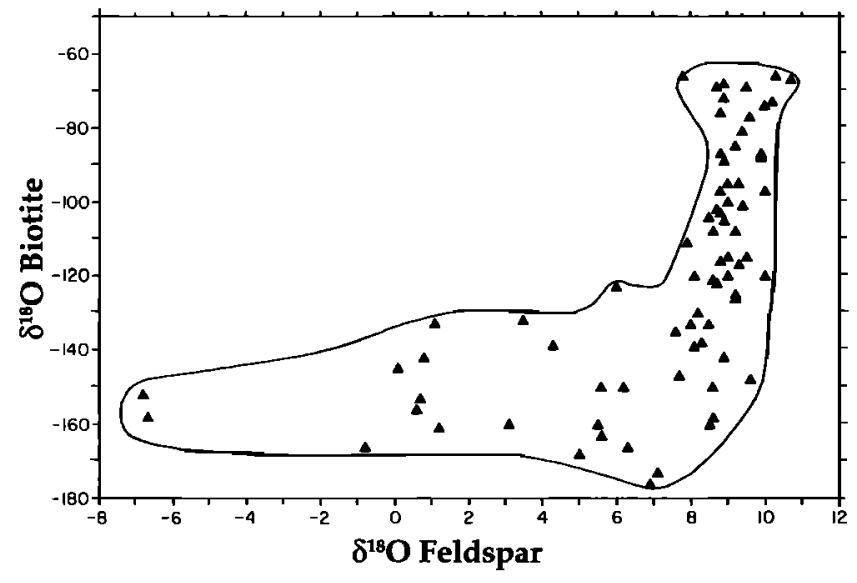

Fig. 4. Graph of $\delta \mathrm{D}$ values in biotiles versus the $\delta^{18} \mathrm{O}$ values of coexisting feldspar in samples from the southem Idaho batholith. Unaltered rocks in this region are far from Tertiary stocks and have $\delta D$ values of about -60 to -80 , typical of deep-seated igneous rocks from many regions of the world; $\delta^{18} \mathrm{O}$ values of feldspar are also high $(>+8.0)$ and are typical of unaltered granitic rocks from many continental areas. The pronounced and coupled lowering of the $\delta \mathrm{D}$ values (to -170$)$ and the $\delta^{18} \mathrm{O}$ values $($ to -6.8$)$ values was caused by interactions of the rocks with substantial volumes of meteoric hydrothermal fluid that had low $\delta \mathrm{D}$ and low $\delta^{18} \mathrm{O}$ values. However, alteration in low water/rock environments can drastically modify the $\delta \mathrm{D}$ values without substantially affecting the $\delta^{18} \mathrm{O}$ values, owing to the low hydrogen content of ordinary rocks, as reflected by the "vertical arm" of the data array (see text). After Criss and Taylor [1983], and including the data of Taylor and Magaritz [1978].

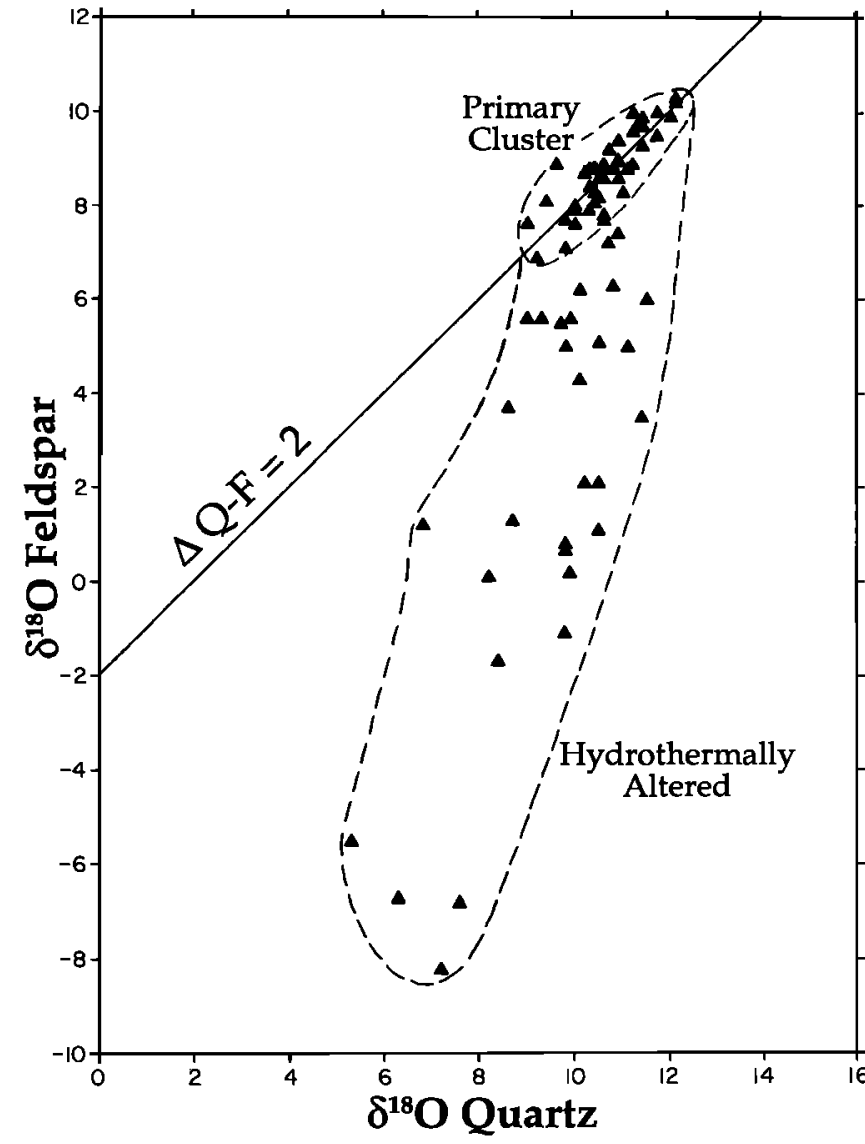

Fig. 5. Graph of the $\delta^{18} \mathrm{O}$ values of coexisting quartz and feldspar from the granitic rocks of the southem Idaho batholith. Petrographically unaltered rocks have high $\delta^{18} \mathrm{O}$ values and normal quartz-feldspar ${ }^{18} \mathrm{O}$ fractionations of $2 \%$ or less that reflect magmatic temperatures. In contrast, samples that have interacted with meteoric hydrothermal fluids have significantly lower $\delta^{18} \mathrm{O}$ values for feldspar, somewhat lower values for quartz, and anomalously large quartz-feldspar $18 \mathrm{O}$ fractionations that have absolutely no temperature significance. This latter effect is explicable in terms of the low fluid-mineral exchange rate of quartz relative to that of feldspar. The net result is the development of pronounced isotopic disequilibrium relationships that are produced by, and diagnostic of, the irreversible process of hydrothermal alteration [after Criss and Taylor, 1983].

Fluid-rock exchange also produces significant isotopic disequilibrium effects in rocks, owing to the differing exchange rates of the various coexisting minerals [Taylor, 1977; Taylor and Forester, 1979; Criss et al., 1987; Gregory et al., 1989]. For example, because quartz is typically relatively inert to oxygen isotopic exchange, whereas feldspar equilibrates rather easily with hot aqueous fluid, a plot of the $\delta^{18} \mathrm{O}$ values of coexisting quartz and feldspar for the altered rocks of the Idaho batholith [Criss and Taylor, 1983] exhibits a linear trend indicative of disequilibrium (Figure 5). As discussed by Gregory and Taylor [1981] and Gregory and Criss [1986], material balance considerations prove that infiltration of a fugitive, oxygen-bearing component must have occurred in rock suites that exhibit such positive-sloped trends.

In any case, hydrothermal systems impart a permanent imprint on rocks that is not only clearly diagnostic of fluidrock interactions but that can also be used to discem the isotopic composition of the fluid in such "fossil" systems long after the cessation of the exchange event. In addition, useful quantitative estimates of the amounts of fluid involved in rock alteration can be made utilizing stable isotope data. 


\section{Petrographic Effects of Fluid-Rock Exchange}

The petrographic effects of meteoric hydrothermal alteration were recently reviewed by Criss and Taylor [1986]. Some other recent studies are by Ferry [1985 a,b], Bird et al. [1986], and Manning and Bird [1986]. Igneous rocks altered under such conditions generally retain much of their primary mineralogy and texture, but develop a subordinate secondary alteration assemblage that is most commonly of the propylitic type. This includes the clouding or argillization of feldspar phenocrysts, the virtually complete serpentinization or chloritization of mafic minerals, and the development of small amounts of calcite, epidote, albite, sphene, opaques, and other minerals.

In detail, the petrographic effects are closely dependent on the physical conditions of alteration. Whereas volcanic country rocks are typically propylitized, alteration assemblages dominated by zeolites, montmorillonite, and calcite commonly develop in the cooler, peripheral parts of the systems, and assemblages dominated by quartz, kaolinite, and alunite develop in zones of acid sulfate alteration near the surface. Intense argillic or sericitic alteration around veins is common, and this may also include silicification.

Higher-temperature assemblages commonly occur within the central intrusions of these systems. In granites, actinolite and coarse-grained epidote may form, and some of the alteration may occur in the biotite stability field, so that the development of chlorite is precluded. In the highesttemperature zones, potassic alteration (caused by either magmatic or meteoric hydrothermal fluids, and commonly by both) is typically associated with the formation of hydrothermal biotite or K-feldspar. An even more extreme case is provided by gabbroic plutons, which have much higher solidus temperatures than granites. In this case much of the fluid infiltration into the crystalline magma body occurs at very high temperatures $\left(>550^{\circ} \mathrm{C}\right)$, well above the stability limit of ordinary hydrous alteration products, and veins are filled with hydrothermal pyroxenes and amphiboles [Norton and Taylor, 1979; Norton et al., 1984; Manning and Bird, 1986]. As a rule of thumb, for a given amount of fluid infiltration, the higher the temperature of alteration, the less mineralogically altered the rocks appear, and the greater the necessity of using stable isotope studies to discern the effects of fluid-rock interaction!

\section{IDENTIFIED TERTIARY METEORIC HYDROTHERMAL SYSTEMS}

\section{Oxygen and Hydrogen Isotope Isopleth Maps}

Systematic mapping of oxygen and hydrogen isotope ratios has disclosed the locations of fossil meteoric hydrothermal systems in numerous terranes throughout the world (see compilation of Criss and Taylor [1986]). These altered regions have several interesting characteristics. The $\delta^{18} \mathrm{O}$ and $\delta \mathrm{D}$ values of the rocks are often markedly lowered, commonly by more than 10 and more than $100 \%$, respectively, relative to their primary (unaltered) values. In addition, the $\delta^{18} \mathrm{O}$ and $\delta D$ values of the outcrops exhibit systematic and contourable variations, reflecting the integrated intensity of pervasive alteration and (to a secondary extent) the locations of major fault and fracture zones. The geometry of the altered zones can in most cases be related to a centrally located igneous intrusion, with the most intense alteration occurring within and peripheral to the sides and the roof of the pluton.

Contour or isopleth maps of relatively small $\left(10-100 \mathrm{~km}^{2}\right)$ regions of $\delta^{18} \mathrm{O}$ and $\delta \mathrm{D}$ lowering related to small intrusions and volcanic centers generally exhibit simple concentric ("bullseye") patterns. In contrast, larger systems (100-1000 $\mathrm{km}^{2}$ ) related to major calderas and subvolcanic batholiths tend to be annular, with an additional oval or ring-shaped low- $18 \mathrm{O}$ zone well outboard of the central low-18 0 zone [Criss and Taylor, 1983]. Gigantic systems $\left(>10,000 \mathrm{~km}^{2}\right)$ related to rift zones or oceanic spreading centers (e.g., Iceland) tend to be linear but are punctuated by local areas of more intense ${ }^{18} \mathrm{O}$ depletion (e.g., "string-of-beads" geometry).

The areas of intense alteration and ${ }^{18} \mathrm{O}$ depletion tend to be sharply defined, both laterally and vertically, by zones of extremely steep ${ }^{18} \mathrm{O}$ gradients. Laterally, the effects are most commonly associated with zones like ring fractures where permeability is strongly enhanced, but they are also related to "compression" of the isotherms by radially inward migration of cool fluid, as well as by sharp buoyant uprise of heated fluid. Vertically, the effects are probably mainly related to the water table and to steep temperature gradients constrained by proximity to the Earth's surface [e.g., Larson and Taylor, 1987]. In contrast, zones of $\delta D$ lowering exhibit more gradual lateral variations, typically extending outward over a much greater area than the associated low- 180 zones. This is a result of the higher effective W/R ratios for $D / H$ exchange given the very low hydrogen contents of ordinary rocks, as well as of the more rapid exchange kinetics of the $\mathrm{OH}$ groups in many minerals.

Stable isotope "mapping" techniques have been applied to numerous igneous terranes in the northwest United States and southern British Columbia. The following discussions describe the principal areas where Tertiary meteoric hydrothermal systems have been identified; locations are given in Figure 1.

\section{Southern British Columbia}

Magaritz and Taylor [1986] measured hydrogen and oxygen isotope ratios of 500 samples, mainly from granitic plutons (Figure 6), along a $700-\mathrm{km}$, E-W traverse across the "accreted terranes" of southern British Columbia (latitudes $49^{\circ}-52^{\circ} \mathrm{N}$ ). Despite the geological complexity and range of intrusive ages (Late Triassic to Tertiary) and although there are "steps" in the isotopic values at some geologic boundaries (e.g., across the Strait of Georgia between the mainland and Vancouver Island), a clear-cut isotopic pattem was found: Although the freshest, least altered samples for the granitic plutons typically have $\delta D$ values within the presently accepted "primary magmatic" $\delta D$ range of -65 to -85 , the subset of heavily altered (chloritized) granitic rocks exhibits steadily decreasing $\delta D$ values from west to east (Figure 7). Thus the calculated ${ }^{18} \mathrm{O} /{ }^{16} \mathrm{O}$ and $\mathrm{D} / \mathrm{H}$ ratios of the waters involved in hydrothermal interactions with the batholiths also show a regular eastward trend of depletion in $\mathrm{D}$ and ${ }^{18} \mathrm{O}$ (Figure 8 ), indicating clearly that these waters were surface-meteoric in origin (although seawater may have been important locally on Vancouver Island). These isotopic trends are similar to the present-day patterns of meteoric waters in the region, with one primary difference. The paleowaters are enriched in D by about $20 \%$ (Figure 8 ), compatible with a northward translation of these terranes, a climatic change, or both. The similarities of the patterns 


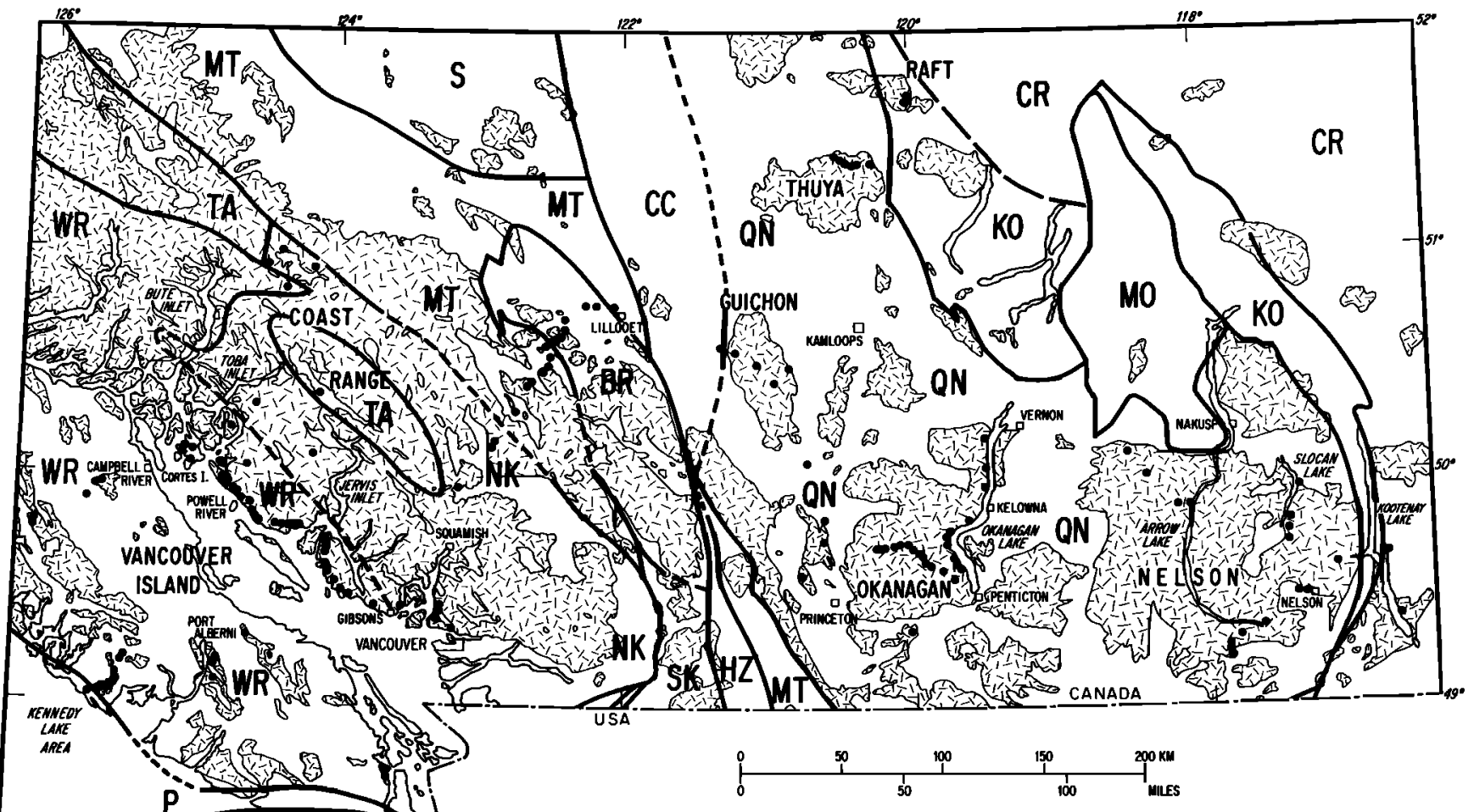

Fig. 6. Generalized geologic map of southem British Columbia, showing the major granitic batholiths (pattem) and the locations of samples (dots) analyzed for $\delta \mathrm{D}$ and $\delta{ }^{18} \mathrm{O}$ [after Magarizz and Taylor, 1986]. The heavy lines outline the various accreted terranes that have recently been identified in this region.

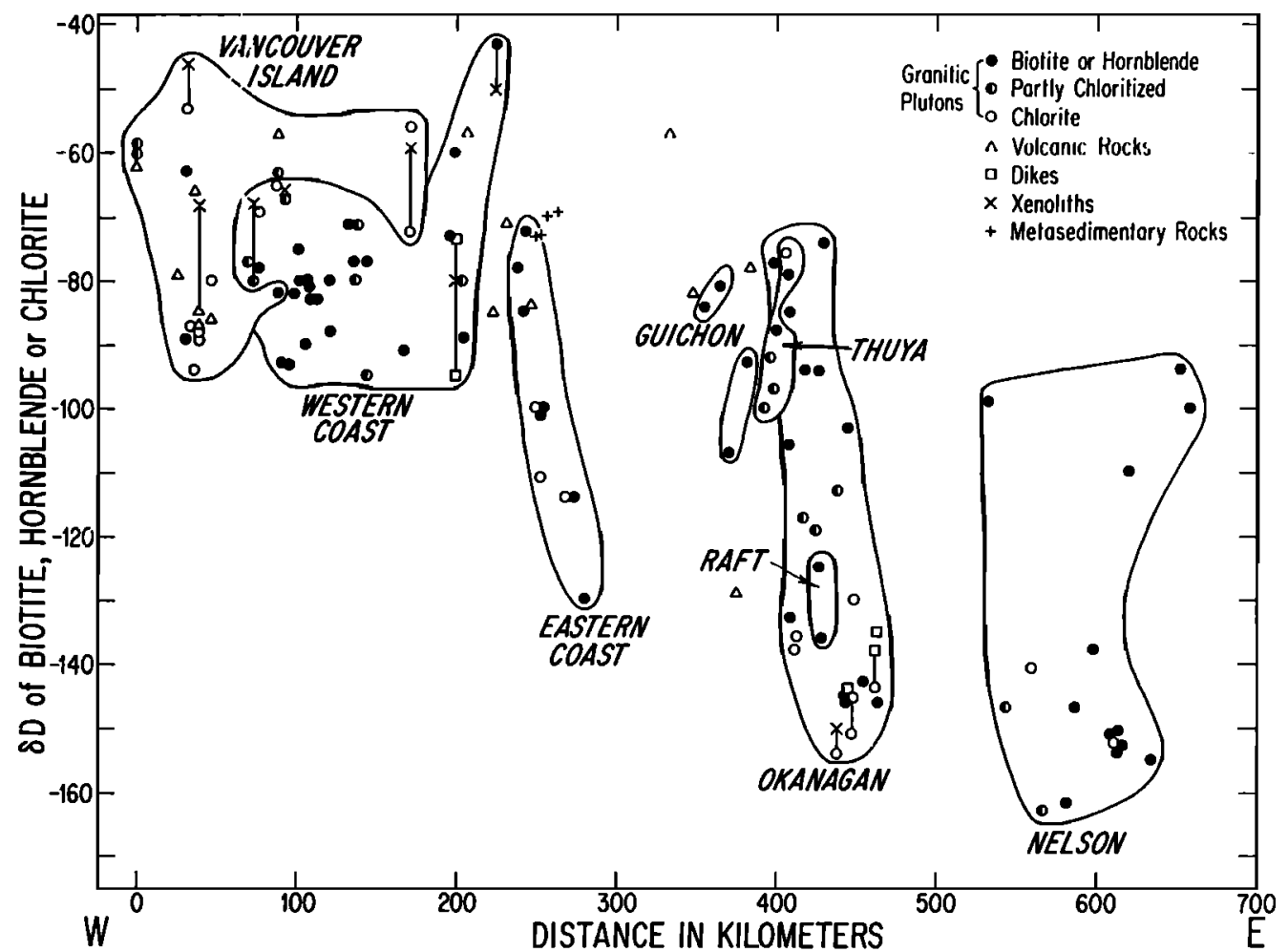

Fig. 7. Plot of $\delta \mathrm{D}$ versus distance eastward from the Pacific Coast of Vancouver Island, for all samples from the granitic batholiths of southem British Columbia studied by Magarizz and Taylor [1986]. 


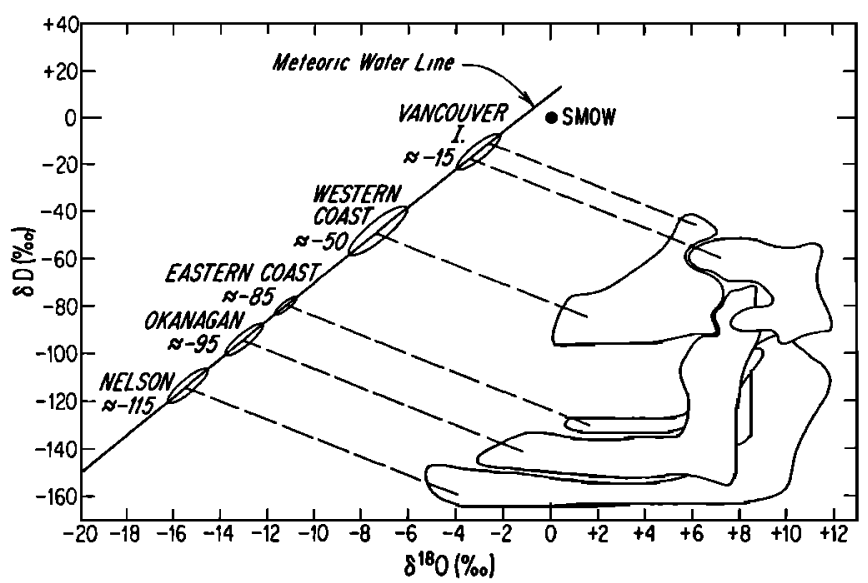

Fig. 8. Plot of $\delta \mathrm{D}$ versus $\delta^{18} \mathrm{O}$ feldspar, showing the various isotopic data point envelopes for the granitic batholiths of southem British Columbia [Magaritz and Taylor, 1986], together with the meteoric water line of Craig [1961], and the calculated $\delta D$ and $\delta^{18} O$ values of the pristine, unexchanged meteoric waters that were the source of the hydrothermal fluids that produced the various "inverted-L" patterns in each batholith. Compare Figure 4.

suggest a topography similar to that of the present day (a mountain chain along the coast) during the early Tertiary.

Two groups of samples are unique in their high $\delta D$ values (Figure 7). The first group is represented by two geographically isolated batholiths (Guichon and Thuya) that do not seem to have been affected by the Tertiary meteoric hydrothermal systems, thus explaining the preservation of their Early Jurassic to Triassic K/Ar ages of about $200 \mathrm{Ma}$. Both of these batholiths are relatively small, and they crop out at considerable distance from any of the younger batholiths of southern British Columbia (Figure 6). Whereas most of the batholiths in British Columbia are composite and contain plutons with a variety of ages ranging from early Mesozoic to mid-Tertiary, the Guichon and Thuya batholiths exclusively exhibit only early Mesozoic ages and appear to have been isolated from the abundant Tertiary meteoric hydrothermal systems in the surrounding areas. The second group is represented by the Jurassic plutons of Vancouver Island; there, the hydrothermal fluids were both D-rich and ${ }^{18} \mathrm{O}$-rich $\left(\delta^{18} \mathrm{O}>\right.$ 0 ), as evidenced by the fact that feldspars in the altered granites are enriched in ${ }^{18} \mathrm{O}$ relative to coexisting quartz. Both "anomalies" can be explained (1) if these terranes were located closer to the equator and/or in a maritime environment at the time of original intrusive and hydrothermal activity, in agreement with available paleomagnetic data, and (2) if subsequent to their accretion to the westem margin of North America they were largely isolated from any Cretaceous or Tertiary hydrothermal events. Excluding these anomalous areas, two distinct ages of meteoric hydrothermal activity can be identified along the $700-\mathrm{km}$ traverse, Cretaceous in the west and early to mid-Tertiary in the east.

If we examine the geographic variations of both $\delta \mathrm{D}$ and $\delta^{18} \mathrm{O}$ throughout southern British Columbia, we obtain a series of "L-shaped" patterns, each one characteristic of a specific geographic area. These effects show up nicely when $\delta D$ is plotted against $\delta^{18} \mathrm{O}$ feldspar (Figure 8). As shown in Figure 4, the horizontal arms of each " $L$ " represent the samples that have been subjected to the highest water-rock ratios; in each case, the horizontal arm displays an approximately constant $\delta \mathrm{D}$ value characteristic of that particular geographic area.
The suite of samples from Okanagan Lake (Figure 6) differs dramatically from those in the main part of the Okanagan batholith, in that every sample is markedly depleted in deuterium, with typical values of -130 to -154 . These samples are also characteristically depleted in ${ }^{18} \mathrm{O}$ and intensely chloritized; they all lie within the horizontal arm of the " $L$ shaped" pattern shown for the Okanagan batholith in Figure 8. Along the Okanagan Lake traverse, the Mesozoic plutons are intruded by several much younger porphyry stocks and dikes (the Eocene Coryell intrusions and associated Princeton volcanics). The dikes and porphyries consistently have lower $\delta^{18} \mathrm{O}$ values than the granitic country rocks that they intrude, even though the Mesozoic plutons have locally been thoroughly depleted in ${ }^{18} \mathrm{O}$. Some of these samples have whole rock $\delta^{18} \mathrm{O}$ values as low as +0.2 and +1.1 and feldspar $\delta^{18} \mathrm{O}$ values as low as -2.8 and -0.2 .

The dramatically larger ${ }^{18} \mathrm{O}$ depletions observed in the vicinity of Okanagan Lake are clearly related to the abundant Tertiary dikes and stocks that occur near this lineament. This was probably a major fracture zone, providing enhanced permeability that would allow much greater circulation of surface waters to great depths. In fact, this zone of weakness (rift?) may have provided upward access for the Eocene magmas as well as downward access for the meteoric hydrothermal fluids.

The Nelson batholith (Figure 6) is also a composite batholith, dominantly Mesozoic in age, whose southwestern portion is intruded by the Eocene Coryell intrusions. All of the strikingly 180 -depleted samples from the Nelson batholith were collected either (1) in close proximity to the Coryell porphyry intrusions, or (2) along the edge of one of the large, narrow, north trending lakes that are so prominent

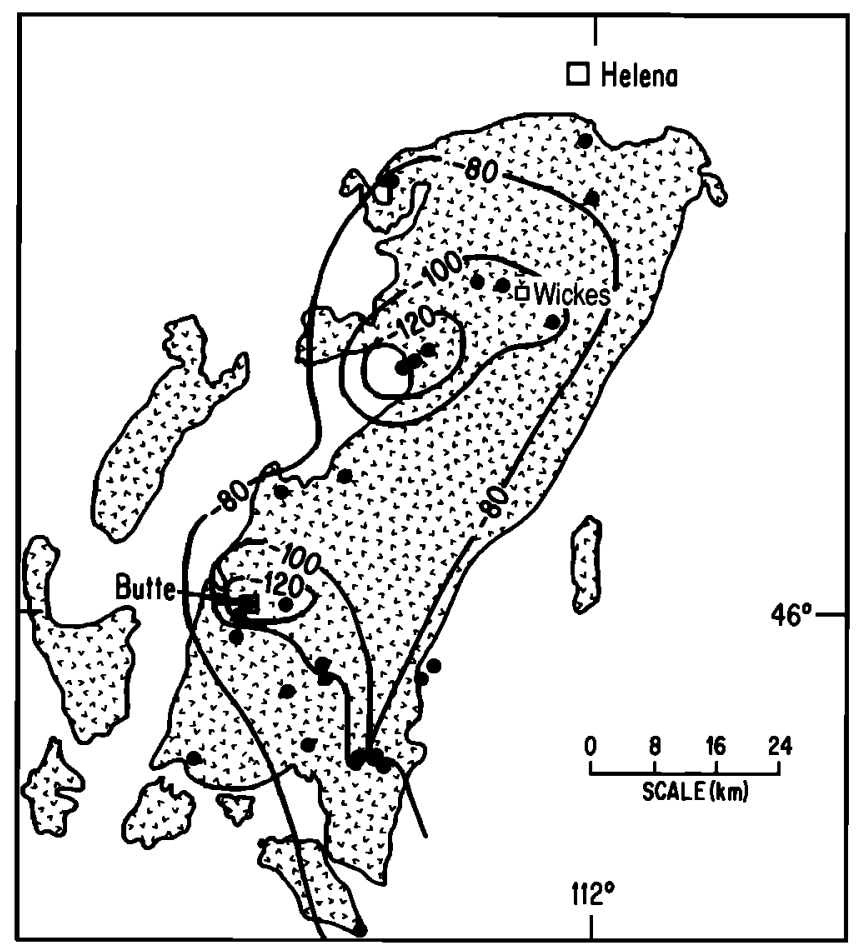

Fig. 9. Contour map of $\delta \mathrm{D}$ values of biotite and homblende (tchlorite) of granitic rocks from the Boulder batholith (patterm), Montana, showing sample localities (solid dots). Pronounced D/H alteration effects due to interactions with meteoric hydrothermal fluids are centered on the mining districts at Butte and Wickes. Slightly modified after Sheppard and Taylor [1974]. 


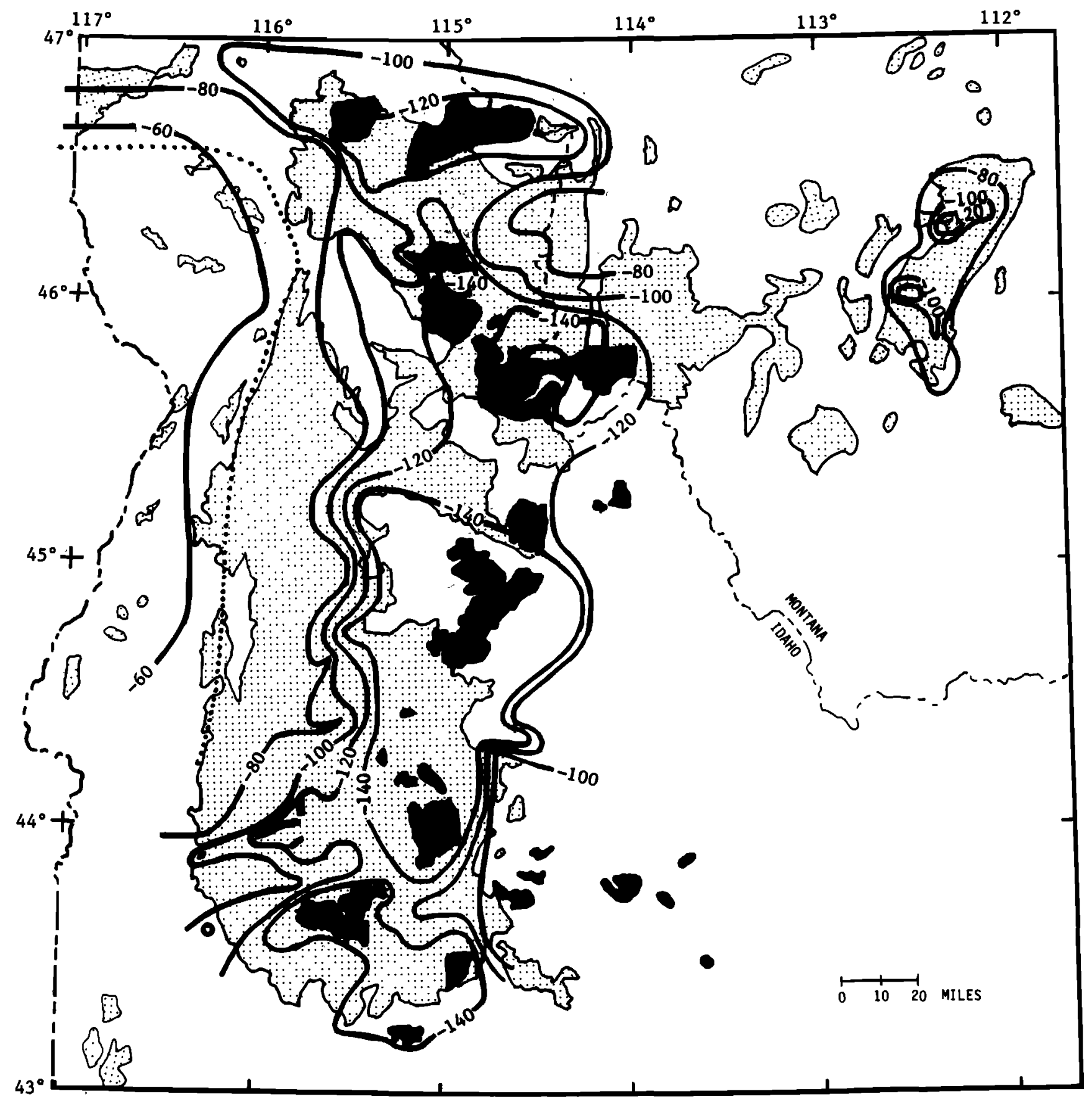

Fig. 10. Contour map of $\delta \mathrm{D}$ values of granitic rocks from the Idaho and Boulder batholiths and other granitic rocks (pattern), compiled from maps by Taylor and Magarizz [1978], Criss and Taylor [1983], Criss and Fleck [1987], and Sheppard and Taylor [1974]. Determinations from the northem Idaho batholith principally represent whole rock samples, whereas determinations from the southem Idaho batholith are principally of biotite (tchlorite), but this difference will not affect general interpretations. Pronounced D/H alteration effects in the Idaho batholith are centered on the epizonal Eocene plutons (solid pattern). In the accreted island arc terranes west of the $0.706 \mathrm{Sr}$ isotope contour (dotted line, modified after Armstrong et al. [1977] and Fleck and Criss, [1985]), some of the relatively high $\delta \mathrm{D}$ values $(>-60)$ possibly reflect seawater-rock interactions, but more study is needed. $\mathrm{D} / \mathrm{H}$ relationships in the Boulder batholith are shown in more detail in Figure 9.

in southern British Columbia. It is thus also probable that both Slocan Lake and Arrow Lake occupy fracture zones that represented major hydrothermal conduits.

\section{Western Montana}

In westem Montana, oxygen and hydrogen isotope evidence for meteoric hydrothermal activity was found in the Boulder batholith, discussed here, and in the northeastern Idaho batholith, discussed in the next section. Sheppard and Taylor
[1974] established that $\delta D$ values in the composite Boulder batholith range from -63 to $-155 \%$, with the altered, low $\delta D$ values being associated with low $\delta^{18} \mathrm{O}$ values, epidote and chlorite alteration, and disequilibrium quartz-feldspar ${ }^{18} \mathrm{O}$ fractionations. The $\delta \mathrm{D}$ values vary in a systematic way (Figure 9). with the lowest values being associated with (1) mineralized areas along the western side (roof) of the batholith in the Butte and Wickes mining districts (see below), (2) small stocks intruded into the Elkhorn Mountains Volcanics, or (3) the subvolcanic roof zone of the batholith. Alteration 
probably occurred in the Late Cretaceous and early Tertiary, and involved meteoric waters with calculated initial $\delta^{18} \mathrm{O}$ values of -13 to -16 .

Idaho

Studies by Taylor and Magaritz [1978], Criss and Taylor [1983], Criss et al. [1982, 1984], and Criss and Fleck [1987] establish that widespread propylitization in the Idaho batholith is associated with isotopically anomalous areas related to Tertiary meteoric hydrothermal systems. Most of these systems are associated with epizonal Eocene plutons (some of which intrude coeval volcanic rocks of the Challis volcanic field). A contour map (Figure 10) shows that $\delta D$ values vary systematically in the batholith, with anomalous values $(<-100)$ occupying at least $25,000 \mathrm{~km}^{2}$, comprising several overlapping zones centered on the Eocene plutons. Zones of ${ }^{18} \mathrm{O}$ depletion and disequilibrium quartz-feldspar ${ }^{18} \mathrm{O}$ fractionations occur interior to the low $\delta \mathrm{D}$ zone but are best developed in the southern Idaho batholith, where fluid circulation was most intense (Figure 11). The $\delta^{18} \mathrm{O}$ and $\delta \mathrm{D}$ values of the pristine (unshifted) meteoric water involved in these systems were about -15 and -110 , respectively, very similar to those responsible for the alteration in the nearby Boulder batholith.

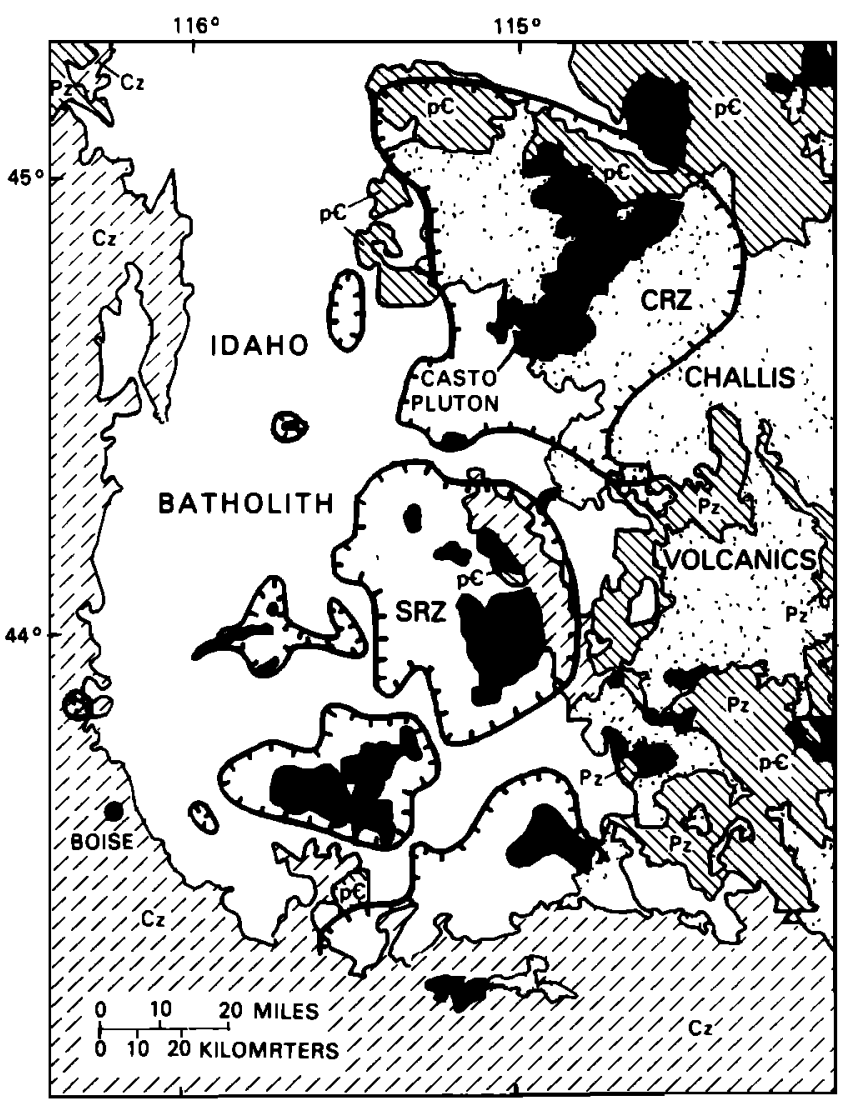

Fig. 11. Generalized geologic map of south central Idaho, showing the southem half of the Idaho batholith (open areas), epizonal Eocene plutons (solid areas), and the Challis volcanics (stippled areas). The hachured line indicates the perimeter of identified zones of intense meteoric hydrothermal alteration and ${ }^{18}$ O depletion. Examples are the Casto ring zone (CRZ), which is centered on the subvolcanic Casto pluton, and the Sawtooth ring zone (SRZ), which is probably related to an Eocene caldera. From Criss et al. [1984] and modified after Criss and Taylor [1983].
The $\delta^{18} \mathrm{O}$ analyses of the rocks can be used to resolve the overlapping $\delta \mathrm{D}$ anomalies into distinct zones of pronounced isotopic exchange (Figure 11). The largest low- ${ }^{18} \mathrm{O}$ zone, the $4500-\mathrm{km}^{2}$ Casto ring zone (CRZ), is centered on the $700-\mathrm{km}^{2}$ Casto pluton and includes the remains of two giant cauldron complexes in the Challis Volcanics [Criss et al., 1984]. Another large $\left(2500 \mathrm{~km}^{2}\right)$ system is the Sawtooth ring zone (SRZ), an annular zone of low $\delta^{18} \mathrm{O}$ values that encompasses the Sawtooth batholith and which probably represents the subvolcanic part of the ring-fracture system of an Eocene caldera (Figure 12) [Criss and Taylor, 1983]. Kerrich and Hyndman [1986] found significant ${ }^{18} \mathrm{O}$ depletions in some mylonitic rocks and associated chloritic breccias in the northeastem part of the Idaho batholith in western Montana. Lewis et al. [1989] showed that $\delta^{18} \mathrm{O}$ depletions in the southeastern part of the Idaho batholith are particularly pronounced near major E-W and NW trending normal faults. Several other low- ${ }^{18} \mathrm{O}$ zones, mostly a few hundreds of square kilometers in extent, are associated with hydrothermal alteration in the contact zones of small Tertiary stocks. Isotopic material-balance $W / R$ ratios of approximately unity characterize most of these anomalous regions, regardless of their size [Criss and Taylor, 1983; Criss et al., 1984].

Zones of ${ }^{18} \mathrm{O}$ depletion also occur in the Challis volcanics [Criss et al., 1984, 1985], as well as in granites and Miocene volcanic rocks in west and southwest Idaho (Zimmerman and Larson, [1989] and R.E. Criss and D.E. Champion (unpublished data, 1982); also see below).

\section{Oregon}

The first ${ }^{18} \mathrm{O} /{ }^{16} \mathrm{O}$ study to demonstrate widespread meteoric hydrothermal effects in North America was that of Taylor [1971], who showed that low $\delta^{18} \mathrm{O}$ values $(-6$ to +4$)$ occur in the country rocks around several Miocene diorite and granodiorite plutons that intrude the Tertiary volcanics of the Western Cascade Range. These were the first fossil meteoric hydrothermal systems to be discovered in North America because the petrographic descriptions of these plutons by Buddington and Callaghan [1936] were perceived to be strikingly similar to the rocks of the Scottish Hebrides and the Skaergaard intrusion, which were the first identified fossil meteoric hydrothermal systems in the world [Taylor, 1968, 1971].

The low- ${ }^{18} \mathrm{O}$ plutonic and volcanic rocks are typically propylitized, and were estimated by Taylor [1971] to comprise a total of $1200 \mathrm{~km}^{2}(8 \%)$ of the area of the Western Cascades (Figure 13). Most rocks collected more than three stock diameters from the intrusive contacts had "normal" $\delta^{18} \mathrm{O}$ values of +5.8 to +8.2 . The isotopic data were interpreted in terms of convective circulation of heated groundwaters during the crystallization and cooling of the central intrusions. A typical plutonic center is the $75 \mathrm{~km}^{2}$ zone of low- $18 \mathrm{O}$ volcanic rocks (average $\delta^{18} \mathrm{O}=+1.1$ ) that crops out around the Bohemia mining district (Figure 13); this district is discussed below in more detail.

Hot spring activity was also associated with peralkaline volcanic centers and calderas of Miocene age that occur along two large fault zones that trend across northwestem Nevada and southeastern Oregon [Rytuba, 1988]. Little is known about stable isotope relations in these systems, although below we give a very brief account of such in the Cordero mercury deposit, Nevada. It is likely that Miocene meteoric 


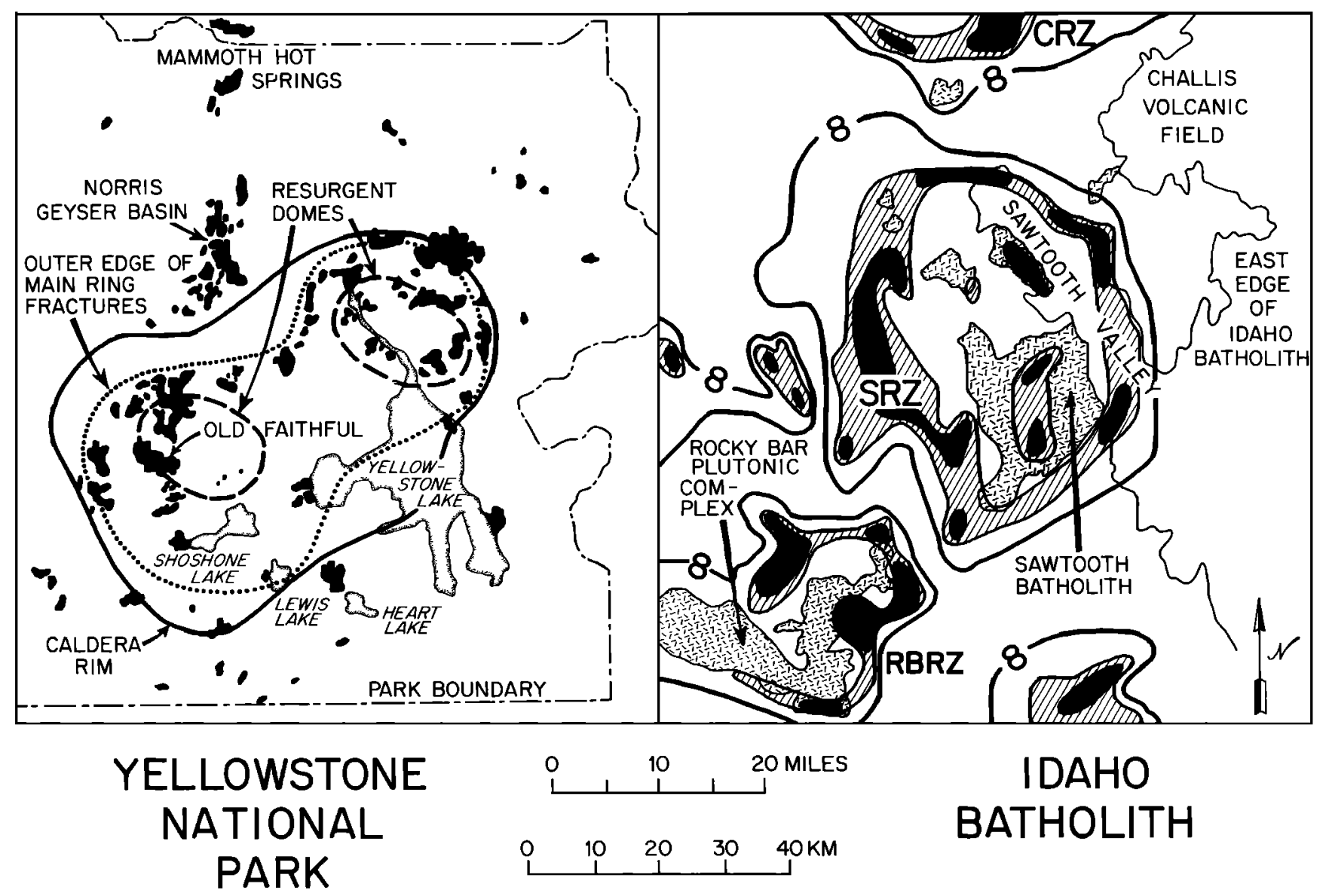

Fig. 12. Comparison of the low- ${ }^{18} \mathrm{O}$ areas of the Sawtooth ring zone (SRZ) and the eastem part of the Rocky Bar ring zone (RBRZ) with the geologic and hydrothermal features associated with the active Yellowstone caldera system, all at the same scale. In Idaho, the areas of the most intense Eocene hydrothermal activity and ${ }^{18} \mathrm{O}$ depletion in the rocks are either ruled $\left(\delta^{18} \mathrm{O}<+4\right)$ or solid $\left(\delta^{18} O<+2\right)$, and are clearly annular in form and centered on Eocene batholiths (pattem; cf. Figure 11). In the Yellowstone area, features developed in the last $2 \mathrm{~m} . y$. as a result of multiple ash flow tuff eruptions are the caldera rim, areas of ring fracture, and resurgent domes. Major areas of present-day discharge of hydrothermal fluid at Yellowstone are shown as solid areas. The major geologic and hydrothermal features in the two areas are highly analogous and probably reflect a similar geologic origin [from Criss and Taylor, 1983].

hydrothermal activity was widespread in Oregon and adjacent parts of Nevada and Idaho, considering that this period was characterized by considerable volcanism, as well as by the profound extensional tectonic activity of the Basin and Range province (see Miocene systems, below).

\section{Washington}

Surprisingly, little work on Tertiary meteoric hydrothermal systems has been undertaken in Washington, although several bodies in the Cascade Mountains are known to contain ${ }^{18} \mathrm{O}$ depleted zones (e.g., the Tatoosh pluton near Mount Rainier). Sheppard et al. [1971] showed that extremely low $\delta^{18} \mathrm{O}$ and $\delta \mathrm{D}$ values occur in a molybdenite deposit in a granite stock at Mount Tolman. Lewis [1984] showed that low $\delta^{18} \mathrm{O}$ values are common in the Republic graben.

R.A. Zielinski and R.E. Criss (unpublished data, 1987) analyzed quartz and whole rock pairs from four samples of the Cretaceous Phillips Lake granodiorite from Flodelle Creek, Stevens County, Washington (F, Figure 1). The samples contain sericite, epidote, chlorite, hematite, and calcite; are cut by numerous small fractures filled with quartz; and show evidence of strain and shear (R.A. Zielinski, written communication, 1987). The $\delta^{18} \mathrm{O}$ values of quartz phenocrysts are all close to +12.0 , whereas the whole rock values are between +3.6 and +5.2 ). Because feldspar is the most abundant mineral in these granodiorites, the quartz-whole rock pairs clearly reflect disequilibrium quartz-feldspar ${ }^{18} \mathrm{O}$ fractionations produced by meteoric hydrothermal alteration (cf. Figure 5), probably related to nearby Tertiary intrusions [see Miller and Engels, 1975]. Surficial uranium mineralization in organic-rich Holocene sediments at this locality cannot be directly related to this alteration event, but it is plausible that the hydrothermal activity introduced the anomalously high uranium concentrations into the Phillips Lake granodiorite, and these later served as the source for the uranium deposits [see Johnson et al., 1987; Zielinski et al., 1989].

\section{Wyoming}

Hildreth et al. [1984] report low $\delta^{18} \mathrm{O}$ values (to -7.5 ) in hydrothermally altered rhyolites and tuffs in drill cores from Yellowstone National Park (YNP, Figure 1). Most of the alteration in this huge silicic volcanic field is related to several successive Quaternary caldera cycles (at 2.0, 1.3, and 


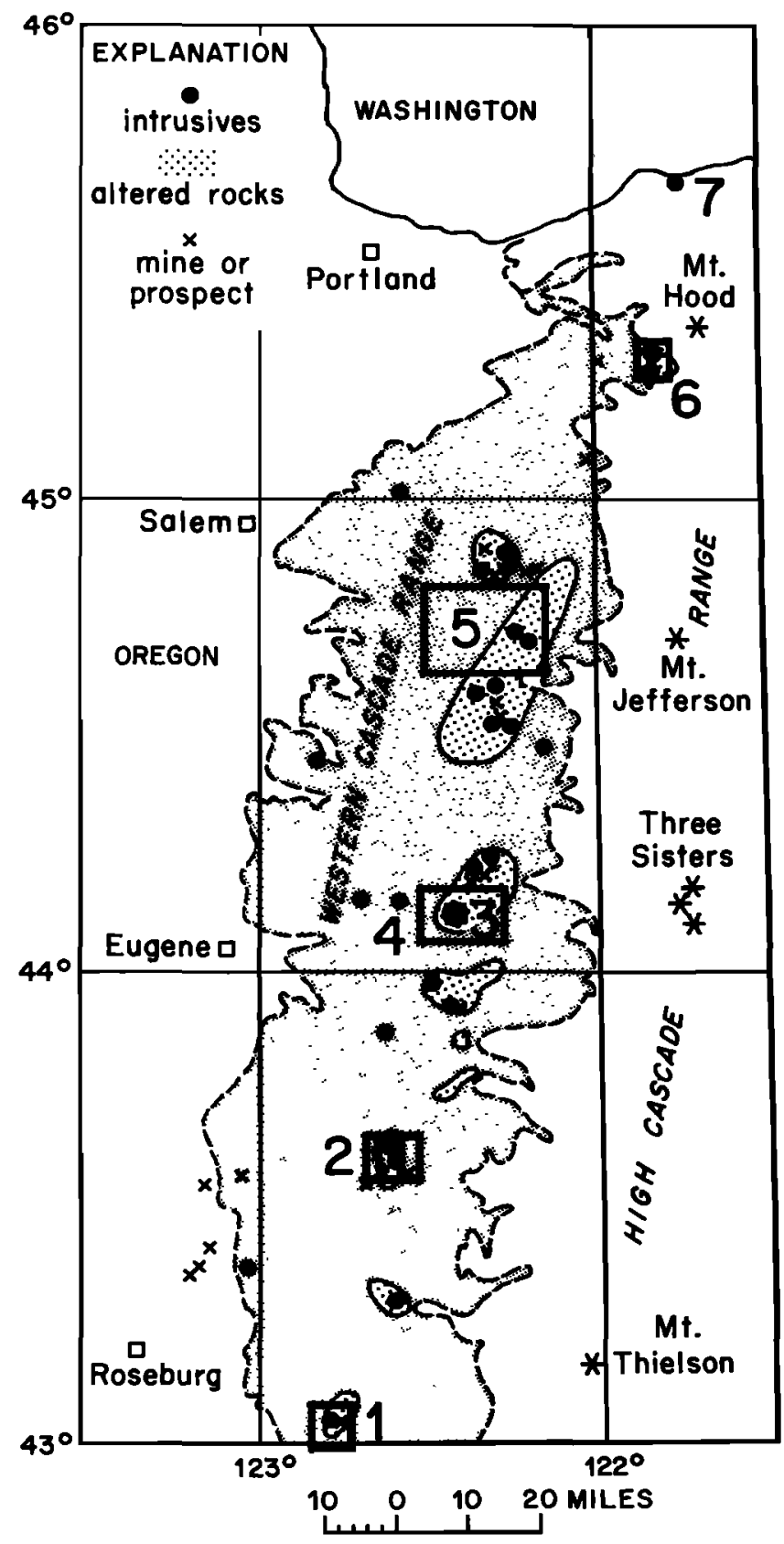

Fig. 13. Map of part of westem Oregon, showing the Tertiary volcanic rocks of the Westem Cascade Range (dark stippled pattem); also shown are the occurrences of Tertiary dioriles and gramodiorites and the areas of propylitic alteration and mineralization (light stipple) studied by Taylor [1971]. It is inferred that the areas shown by the light stipple are all depleted in ${ }^{18} \mathrm{O}$. The large numbers indicate the various localities studied by Taylor [1971]. Area 2 is the Bohemia mining district, shown in Figure 17.

$0.6 \mathrm{Ma}$ ); however the hydrothermal activity was probably initiated in the Pliocene and it continues with considerable intensity today (Figure 12).

G. C. Solomon (unpublished data, as cited in Criss and Taylor, [1986]) mapped a $50-\mathrm{km}^{2}$, low- ${ }^{18} \mathrm{O}$ zone around a small granodiorite stock at Meadow Creek. This stock intrudes the Eocene volcanic rocks of the Absaroka Mountains, a short distance southeast of Yellowstone National Park.
REI ATIONSHIP OF ORE DEPOSITION TO METEORIC HYDROTHERMAL SYSTEMS

Paleocene System

The giant Butte ore deposit is hosted within the Late Cretaceous Boulder batholith, a composite mass emplaced into a thick roof of genetically related rocks of the Elkhorn Volcanics (Figure 9). Although $\mathrm{K}$-Ar ages indicate emplacement of the batholith at approximately 78 to $68 \mathrm{Ma}$ [Tilling et al., 1968], apparent ages on the alteration assemblages indicate that the mineralization occurred in Paleocene time, at least 5-10 m.y. after emplacement of the late plutons [Meyer et al., 1968]. The fabulously rich, E-W trending, Main Stage veins valued for $\mathrm{Cu}-\mathrm{Zn}-\mathrm{Pb}-\mathrm{Mn}$ at Butte may postdate an earlier, low-grade porphyry-style mineralization.

The study of Garlick and Epstein [1966] established the large variation in $\delta^{18} \mathrm{O}$ values of vein quartz at Butte. Some of the Main Stage veins contain quartz with $\delta^{18} \mathrm{O}$ values as low as -0.1 , proving that a component of low- ${ }^{18} \mathrm{O}$ meteoric hydrothermal fluid was involved in their genesis. Garlick and Epstein [1966] also demonstrated that the quartz monzonite wall rock is substantially depleted in ${ }^{18} \mathrm{O}$ adjacent to the Main Stage veins.

Subsequently, Sheppard and Taylor [1974] obtained oxygen and hydrogen isotope data on the Butte ore deposits and showed that meteoric hydrothermal waters were the dominant constituent of the ore-forming fluid during Main Stage mineralization. Numerous fracture conduits were constantly being opened by tectonic forces and then partially closed by mineral deposition during this stage [Meyer et al., 1968], and this provided the necessary fracture permeability to allow circulation of large quantities of meteoric water to paleodepths of at least $3 \mathrm{~km}$. No evidence for an important magmatic water contribution to these fluids was -found. Fluids that were strongly depleted in ${ }^{18} \mathrm{O}$ were shown to be responsible for the advanced argillic assemblages. Sheppard and Taylor [1974] also showed that the earlier, pre-Main Stage mineralization at Butte involved high ${ }^{18} \mathrm{O}$ fluids but could not determine whether these fluids represented magmatic waters or meteoric hydrothermal solutions that had undergone a large ${ }^{18} \mathrm{O}$ shift. As discussed above, Sheppard and Taylor [1974] also established that meteoric hydrothermal activity and its associated alteration products are widespread in the Boulder batholith, with large-scale $\delta \mathrm{D}$ anomalies being centered on the Butte and Wickes ore districts (Figure 9).

Criss and Fleck [1987] showed that Paleocene plutons, in addition to Cretaceous and Eocene plutons, are common in the northern part of the Idaho batholith. It is possible and perhaps likely that plutons of similar age are present in the nearby Boulder batholith, and that they provided the heat energy needed to create the meteoric hydrothermal system during Main Stage time. Conversely, although most of the meteoric hydrothermal activity and significant mineralization in the Idaho batholith is believed to be Eocene in age (Figure 10 , also see below), the possibility exists that important mineralized meteoric hydrothermal systems of Paleocene age also occur there.

\section{Eocene Systems}

Republic, Washington. The Republic Au-Ag district ( $R$, Figure 1) includes classic epithermal mineralization hosted 
within a several kilometer thick sequence of Eocene volcanic rocks within the Republic graben [Lindgren and Bancroft, 1914; Muessig, 1967; Pearson and Obradovich, 1977]. Lindgren and Bancroft concluded that the ore deposits are closely related to a $5 \mathrm{~km}^{2}$ quartz latite porphyry stock that cuts the volcanic sequence, although Muessig [1967] argued that this intrusion (the Scatter Creek rhyodacite) predates ore deposition.

The veins are typically well defined and north trending, with a gangue that is delicately laminated, and commonly made up of chalcedonic quartz with minor calcite and adularia. Ore minerals occur in irregular black layers consisting of tetrahedrite with minor chalcopyrite, free gold, electrum, and some Ag-, Sb-, S-, $\mathrm{Cu}$ - and Se-bearing phase or phases; ore minerals also occur as thick, black encrustations in vugs. The volcanic wall rocks are propylitized within a kilometer or so of the veins, and are commonly silicified near the veins [Lindgren and Bancroft, 1914].

An oxygen isotope study by Lewis [1984] disclosed abundant evidence for the dominance of low-18 O fluid at Republic. The $\delta^{18} \mathrm{O}$ values of hydrothermal quartz $(+0.2$ to $+5.8)$ and calcite $(-1.4$ to +5.8$)$ indicate that the $\delta^{18} \mathrm{O}$ of the ore fluid progressively decreased from -0.5 to -8.5 over time [Lewis, 1984]. Several samples of volcanic wall rock collected within $50 \mathrm{~m}$ of the veins at the Knob Hill Mine also have low $\delta^{18} \mathrm{O}(-3.1$ to +3.1$)$, with the lowest values typically being closest to the veins.

Idaho Batholith. Au-Ag and other deposits: Ever since Ross [1928, 1934] demonstrated that Tertiary and Cretaceous plutonism were both important in the Idaho batholith, most workers have recognized that significant ore deposits were formed during both periods [e.g., Ross, 1931; Finch, 1932; Bergendahl, 1964; Mclntyre et al., 1976, Criss and Fleck, 1987]. However, significant disagreement arose over the relative importance of Cretaceous and Tertiary mineralization, and this problem is still unresolved. Ross [1931] argued that most of the ore deposits of central Idaho are Mesozoic and related to the Idaho batholith, whereas Anderson [1951] argued that most of the deposits are Tertiary and that the Mesozoic rocks of the Idaho batholith are metallogenetically insignificant. Lund et al. [1986] found Late Cretaceous ages in sericite associated with gold-bearing quartz veins in the Buffalo Hump district. However, no low $\delta^{18} \mathrm{O}$ or $\delta \mathrm{D}$ rocks were found by Taylor and Magaritz [1978], Criss and Taylor [1983], Fleck and Criss [1985] or Criss and Fleck [1987] in this region, so the Buffalo Hump deposit and certain other quartz-sericite veins in the batholith probably do not have a meteoric hydrothermal origin (Figure 10; see below).

The majority of ore deposits within the Idaho batholith are $\mathrm{Au}$ and $\mathrm{Ag}$ deposits, commonly with significant but generally subordinate $\mathrm{Pb}, \mathrm{Zn}, \mathrm{Cu}, \mathrm{W}, \mathrm{F}$, and/or $\mathrm{Sb}$ values [see Bergendahl, 1964; Ross, 1941; Anderson, 1939, 1943, 1947]. Most are simple epithermal or mesothermal fissure veins that occupy shear zones within the host granite. The most common gangue materials are quartz and altered (usually sericitized) wall rock. The precious metals may be free or associated with sulfides, and complex metal-S-As-Sb compounds also occur. The ore deposits are commonly associated with pre-ore, hypabyssal porphyry dikes and with syn-ore and post-ore lamprophyre dikes that also cut the host granite, relations that Anderson [1951] argued are indicative of formation during the Tertiary.
Criss and Taylor [1983] demonstrated that most of the ore deposits in the southern half of the Idaho batholith occur near the mapped perimeter of the low-18 $\mathrm{O}$ zones produced by Tertiary (mostly Eocene) hydrothermal activity (Figure 14). This spatial correspondence argues strongly for formation of these ore deposts during Tertiary time [Criss and Taylor, 1983] (Figure 14). However, Criss and Fleck [1987] noted no such strong correspondence in their study of the northern Idaho batholith (Bitterroot lobe and northernmost Atlanta lobe), where most of the ore deposits occur close to contacts between granitic and metasedimentary rocks.

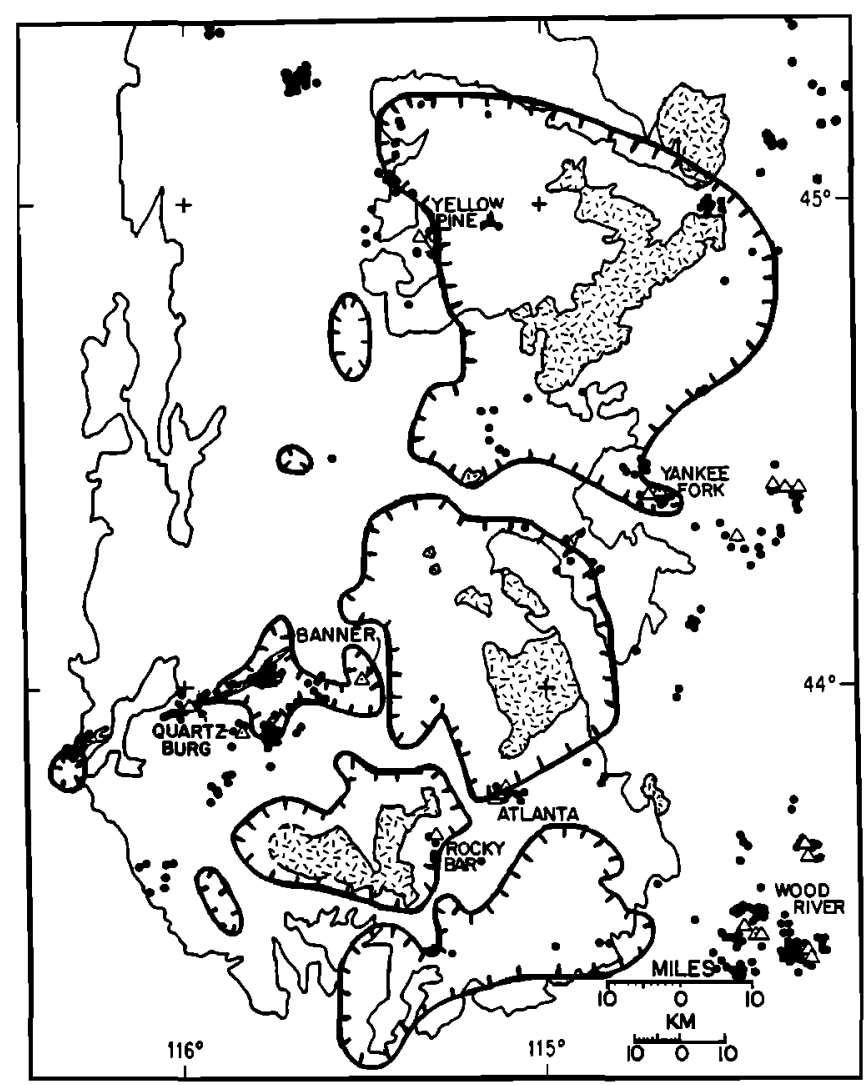

Fig. 14. Map showing the locations of productive mineral deposits in south central Idaho (solid circles; large triangles represent major producer), Tertiary stocks (pattern), and the perimeter of zones of intense Tertiary hydrothermal alteration (hachured line) from Figure 11. Major districts are labeled, and many are discussed in the text. Note the pronounced spatial association of the major mineralized areas with the perimeter of the zones of intense Tertiary hydrothermal activity and the general lack of productive deposits in areas devoid of such activity, such as in the west-central part of the southem Idaho batholith. Modified after Criss and Taylor [1983], and utilizing unpublished mineral locality data provided by J. A. Noble.

Work in progress establishes that low $\delta \mathrm{D}$ values, ranging from -123 to -158 for sericite and fluid inclusions associated with quartz veins, characterize several of the ore deposits in the southern Idaho batholith, including Atlanta ( $\mathrm{Au}-\mathrm{Ag}$ ), Rocky Bar (Au-Ag), Stanley (F), and Hermada (Sb). Such examples directly confirm the meteoric hydrothermal origin of these deposits inferred by Criss and Taylor [1983] on the basis of their spatial association with the large low-18 $\mathrm{O}$ zones. Much higher $\delta D$ values, ranging from -50 to -56 , were found for vein sericites from the Buffalo Hump ( $\mathrm{Au}$ ) district and the Lucky Strike (Old Mount Marshall; Au) and Rainbow NE (Sb) 
prospects, which are not clearly related to low $18 \mathrm{O}$ zones and probably are Cretaceous in age. The $\delta^{18} \mathrm{O}$ values of mineralized quartz veins in the southern Idaho batholith vary widely $(+4.1$ to +16.9$)$. Most of these values are indicative of deposition at moderate temperatures in the presence of an evolved meteoric hydrothermal fluid that had earlier undergone a significant ${ }^{18} \mathrm{O}$-shift (from original values as low as -15 to values as high as +2 ). However, fluid $\delta^{18} \mathrm{O}$ values as high as +8 may characterize the Cretaceous deposits. Quartz-sericite $18 \mathrm{O} /{ }^{16} \mathrm{O}$ fractionations indicate vein formation at temperatures of $160^{\circ}$ to $260^{\circ} \mathrm{C}$, if precipitation of both phases under equilibrium conditions is assumed.

The Yellow Pine district: Yellow Pine is a complex, multistage ore district that has produced considerable $\mathrm{Au}, \mathrm{W}$, $\mathrm{Ag}, \mathrm{Sb}$, and $\mathrm{Hg}$, and formerly was thought to contain the largest antimony reserve in the United States [White, 1940; Cooper, 1951]. This deposit is included among the Eocene systems in this report, although a definitive determination of the actual age(s) of mineralization has not been made (see below). The main deposit at the Yellow Pine Mine occurs within a 50-m-wide, north trending shear zone in the Idaho batholith that bends abruptly to the northeast at the mine, adjacent to a large roof pendant of metasedimentary rock and several pegmatite, aplite, porphyry, lamprophyre, and basalt dikes [White, 1940; Cooper, 1951]. Disseminated cinnabarpyrite ore is concentrated in altered limestone which is locally converted to jasperoid [Ross, 1941].

At the Yellow Pine Mine, earlier sulfide mineralization characterized by disseminated gold-bearing pyrite and arsenopyrite and associated $\mathbf{K}$-silicate and sericitic alteration was followed by scheelite-carbonate-quartz mineralization and then by antimony-silver mineralization which occurs both as disseminated ore and as small quartz-stibnite veinlets [White, 1940; Cooper, 1951; Lewis, 1984]. Cookro and Silberman [1986] found textural evidence for late stage deposition of cryptocrystalline and chalcedonic quartz associated with the scheelite and stibnite; this late quartz probably formed in an epithermal environment at low $\left(<200^{\circ} \mathrm{C}\right)$ temperatures.

Criss and Taylor [1983] did not observe any low $\delta^{18} \mathrm{O}$ values in the Yellow Pine district, but low 180 rocks were found within the Eocene Challis Volcanics a few kilometers to the east [Criss et al., 1984]. A more detailed stable isotope study of the Yellow Pine district by Lewis [1984] disclosed some low $\delta^{18} \mathrm{O}$ values in gangue minerals, for example, in adularia associated with $\mathrm{Au}(+5.2$ to +7.7$)$ and in carbonates associated with several ore stages $(+1.5$ to +20.9 , but mostly $<+7.5$ [Lewis, 1984]). As might be expected, rather high $\delta^{18} \mathrm{O}$ values were found to be associated with the late stage, low-temperature ores; for example, hydrothermal quartz at the Hermes Mine (Hg) ranges from +11.4 to +15.0 [Lewis, 1984]. Lewis [1984] and Lewis and Shieh [1986] interpreted these results in terms of deposition of ore in an environment of progressively declining temperatures and $\delta^{18} \mathrm{O}$ fluid values $(+3$ to -14$)$, preceding the eruption of the Challis Volcanics.

Cookro et al. [1988] found $\delta \mathrm{D}$ values of -79 to -84 in sericite from the Yellow Pine district and values of -94 to -114 in fluid inclusions released by crushing quartz veins. They suggest that a Late Cretaceous event resulted in the deposition

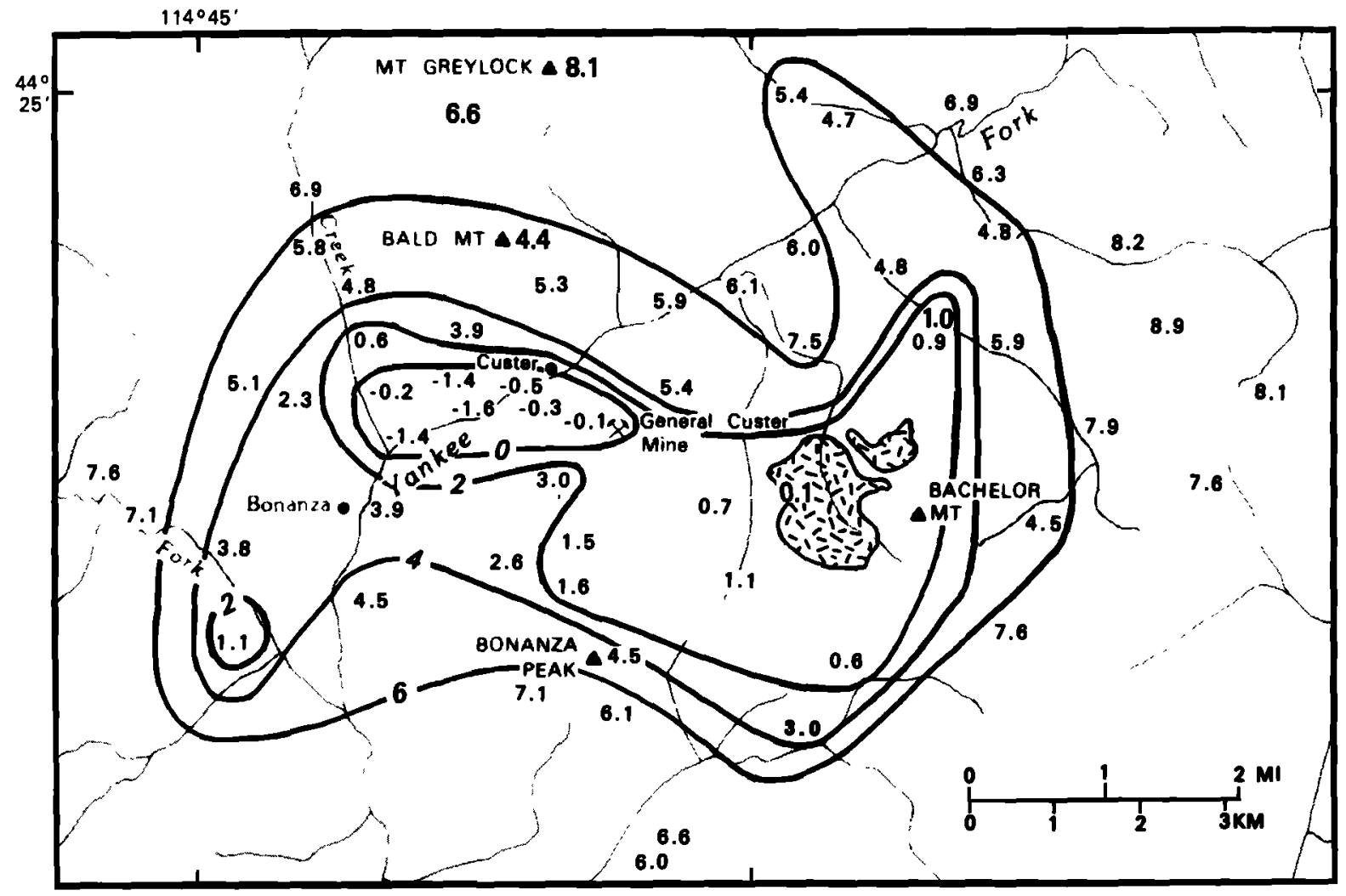

Fig. 15. Contour map of $\delta^{18} \mathrm{O}$ values of the Yankee Fork district, Idaho (for location, see Figure 14). Most values represent, analyses of intermediale lavas of the Challis volcanics, but bold numbers represent other lithologies. The values define a $75 \mathrm{~km}^{2}$ zone of pronounced $18 \mathrm{O}$ depletion that is related to intense circulation of meteoric hydrothermal fluids about subvolcanic stocks, one of which crops out immediately west of Bachelor Mountain (pattem). Modified after Criss et al. [1985]. 
of early sulfides and gold associated with albite and adularia, and that an Eocene meteoric hydrothermal event resulted in the deposition of $\mathrm{Au}, \mathrm{Ag}$, stibnite, scheelite, arsenopyrite, pyrite, and $\mathrm{Hg}$, all in quartz and quartz veins of distinctly epithermal character. Additional work on this complex district is in progress, but available evidence indicates that both Cretaceous and early Tertiary alteration and mineralization are present. Certain highly productive ore deposits in the northwestem United States may have been formed when Tertiary meteoric hydrothermal systems concentrated older, lower-grade ore deposits.

Challis Volcanic Field, Idaho. Several epithermal ore deposits occur in Eocene rocks of the Challis Volcanics, thick sections of which are preserved east of the Idaho batholith. These volcanics and associated intrusions have $\mathrm{K}$-Ar ages of 51-45 $\mathrm{Ma}$ and include widespread intermediate to mafic volcanic products as well as rhyolitic ash flow tuffs erupted from two large caldera complexes [McIntyre et al., 1982]. The mineral deposits occur as simple fissure veins or as stockworks and disseminations, and most are valued for their $\mathrm{Ag}$ and $\mathrm{Au}$ contents, although significant deposits of $\mathrm{F}$ and $\mathrm{Sb}$ also occur. Useful descriptions of these deposits are provided by Umpleby [1913], Ross [1927, 1941], and Anderson [1929. 1949].

An extremely large zone, $4500 \mathrm{~km}^{2}$, of ${ }^{18} \mathrm{O}$-depleted rocks occurs around the $700 \mathrm{~km}^{2}$ Casto granite pluton (Eocene) and within the two large cauldron complexes on its flanks (Figure 11) [Criss et al., 1984]. Low $\delta^{1 B_{0}} \mathrm{O}$ values have also been found in volcanic wall rocks in every mining district in the Challis Volcanics that has so far been investigated, namely, in the precious metal deposits at Yankee Fork (to -8.8), Thunder Mountain (to +1.6), Lava Creek (to -1.5 ), and Singheiser (to -0.7 ), as well as in the fluorite deposits at Myers Cove (to -5.4; above data from Criss et al. [1984, 1985]; also F. Moye and R. E. Criss, (unpublished data, 1988)). In addition, Constantopoulos [1988] found that several fluorite deposits within and near the Challis Volcanics were formed at low

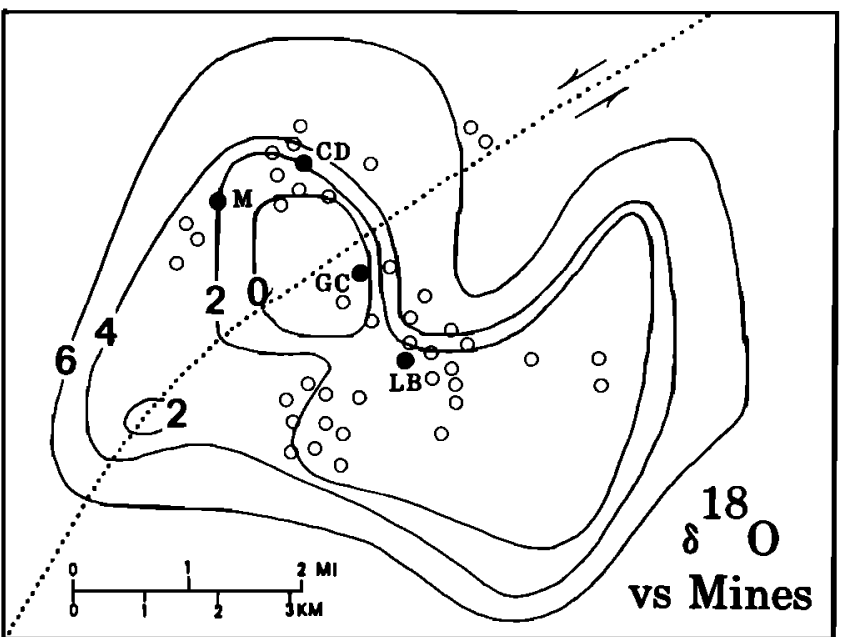

(mostly $130^{\circ}-160^{\circ} \mathrm{C}$ ) temperatures in the presence of lowsalinity fluid $(<1.5 \mathrm{wt} \%)$. These results provide strong evidence that Tertiary meteoric hydrothermal fluids were important in the generation of all of the above deposits.

A detailed isotopic study of the Yankee Fork district revealed a rather small $\left(75 \mathrm{~km}^{2}\right)$ and distinct low- ${ }^{18} \mathrm{O}$ zone that exhibits a simple bullseye pattern, possibly representing an Eocene stratovolcanic center (Figure 15) [Criss et al., 1985, 1988]. A marked spatial correlation between the locations of productive mineral deposits and areas of low ${ }^{18} \mathrm{O}$ was found, with the mineralization being confined to zones of steep ${ }^{18} \mathrm{O}$ gradients where former temperature and $W / R$ gradients changed most rapidly (Figure 16). This zone of steep gradients also approximately marks the boundary between low-temperature alteration assemblages containing expandable clay minerals and higher temperature assemblages containing chlorite \pm sericite. Criss et al. [1985] showed that the ore deposits in the district are closely associated with the perimeter of a zone in which the magnetizations of the host volcanics were reduced to extremely low levels, probably as a result of sulfidation (Figure 16).

Proof of the dominance of meteoric hydrothermal fluids in vein formation at the Yankee Fork district is provided by the low $\delta^{18} \mathrm{O}$ values of quartz in the General Custer vein $(+3.8)$ and of a typical stringer at the Sunbeam Mine $(+1.5)$. The $\delta D$ value of -150 for fluid released by heating the quartz vein from the General Custer mine corroborates this conclusion [Criss et al., 1985].

\section{Miocene Systems}

Western Cascade Range, Oregon. The Western Cascade Range contains several small Tertiary base-metal and gold deposits. The total production is nearly $\$ 1,000,000$, more than half of which represents gold from the Bohemia district [Callaghan and Buddington, 1938]. Nearly all of the veins are NW trending, although the Bohemia district also contains

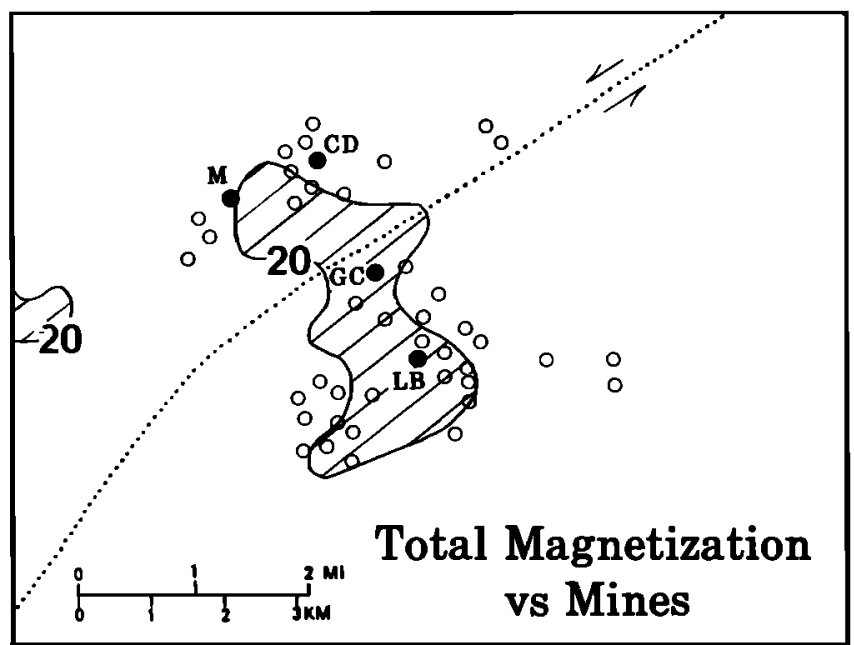

Fig. 16. Locations of productive mine localities relative to the contours of whole rock $\delta^{18} \mathrm{O}$ values and rock magnetizations in the Yankee Fork district, all reconstructed assuming $2 \mathrm{~km}$ of left-lateral displacement on the Custer fault (dotted line; cf. Figure 15). Note the close spatial association of the epithermal $\mathrm{Ag}$-Au deposits (dots and circles) with the zones of high- ${ }^{18} \mathrm{O}$ gradients and with the perimeter of the zone of extremely low rock magnetizations (ruled pattem). This association is particularly well shown by the major producing mines, most importantly the General Custer (GC) and also the Lucky Boy (LB), the Charles Dickens (CD), and the Morrison (M), with a combined production of about $\$ 10$ million. These relationships probably indicate a close association of the ore zones with steep former gradients in temperature and possibly with fluid/rock ratio and oxygen and sulfur fugacities [from Criss et al., 1985]. 
veins that trend nearly E-W. The veins are characteristically epithermal and typically consist of brecciated country rock cemented with vuggy quartz that contains sphalerite, galena, chalcopyrite, and pyrite [Callaghan and Buddington, 1938].

In his study of alteration in the westem Cascade Range, Taylor [1971] demonstrated that a $75 \mathrm{~km}^{2}$ zone of low- ${ }^{18} \mathrm{O}$ volcanic rock (average +1.1 ) occurs in the Bohemia mining district (Figure 17). Two small $(<3 \mathrm{~km}$ ) stocks of augite granodiorite and several dikes and plugs intrude the andesites, tuffs and breccias in the central part of the concentric low- ${ }^{18} \mathrm{O}$ zone. A 0.3 - to $0.6-\mathrm{km}$-wide contact metamorphic aureole of tourmaline hornfels surrounds the larger stocks and grades into a zone of propylitic alteration at greater distance [Buddington and Callaghan, 1936; Callaghan and Buddington, 1938].

Lake County, Oregon. An important $\left(>10^{7} \mathrm{~g} \mathrm{Au}\right)$, volcanichosted gold deposit occurs at Quartz Mountain, approximately $40-\mathrm{km}$ north of the California-Oregon border (QM, Figure 1) [M.G. Sawlan, personal communication, 1991]. The gold occurs in quartz-adularia veinlets in silicified Miocene rhyolite domes, disseminated in rhyolite tuff adjacent to these domes, and in quartz-adularia veins in basaltic andesite [Sawlan et al., in press]. In addition, high-grade ore occurs locally in mineralized fault breccia [Sawlan et al., in press]. Cinnabar, alunite and opal replacements also occur in the district, and there has been minor production of mercury from the cupolas of thyolite domes [Sawlan et al., in press; Brooks, 1963]. Six samples of quartz, chalcedony and opal from the Quartz Mountain district, many of which are gold bearing, have $\delta^{18} \mathrm{O}$ values of +7.5 to +13.5 (M.G. Sawlan and R.E. Criss, unpublished data, 1988). Assuming temperatures of $100^{\circ}$ $200^{\circ} \mathrm{C}$, fluids with $\delta^{18} \mathrm{O}$ values between -14 and $+1 \%$ would have precipitated these materials; it is evident that these fluids were predominantly of meteoric origin.

Silver City and DeLamar, Idaho. The epithermal veins in the Silver City region occur in Miocene basalts and rhyolites and in Cretaceous granitic rocks [Piper and Laney, 1926] (also see Ekren et al., [1984]). Typical veins are dominated by milky quartz, have a NNW trend, and are remarkable for their

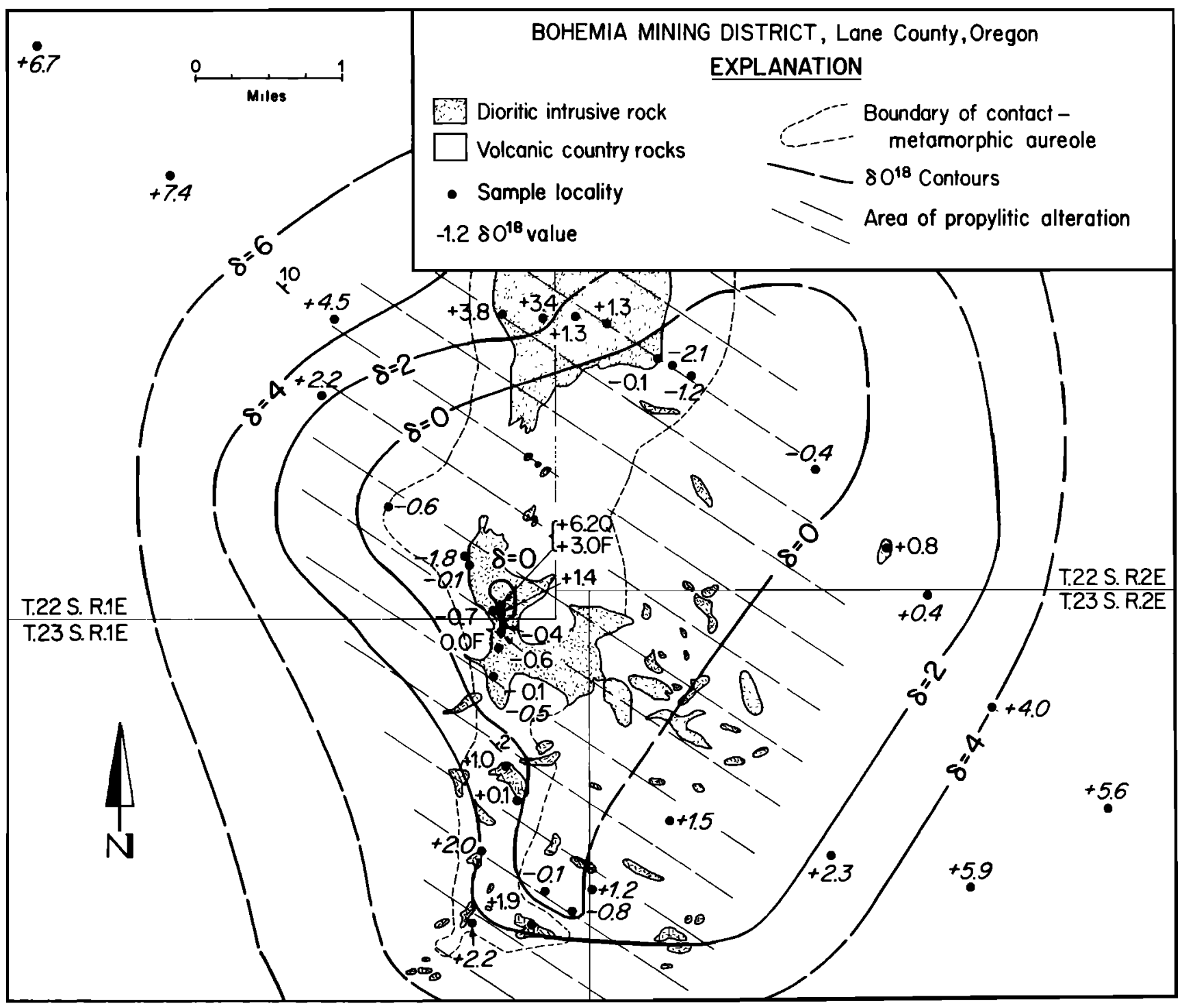

Fig. 17. Contour map of $\delta^{\mathbf{1 8}} \mathrm{O}$ values of volcanic country rocks, intrusions, and a few veins from the Bohemia mining district, Oregon. The locations of intrusions are indicated by the stippled partem, and the zone of propylitic alteration is ruled. The $18 \mathrm{O}$ and alteration effects are related to convective circulation of heated groundwaters around the stocks [from Taylor, 1971]. 
continuity. Chalcedonic and cellular quartz also occur, as do quartz crystals that occur with ore minerals in vugs; other gangue minerals include hydrothermal feldspar and carbonates [Piper and Laney, 1926]. Ore minerals are numerous and complex, the most important being selenides, sulfantimonides, sulphides, and electrum [see Piper and Laney, 1926]. More than $\$ 40,000,000$ of $\mathrm{Ag}$ and $\mathrm{Au}$ was historically produced, and a large-scale open pit operation near DeLamar is now exploiting low-grade silver and gold associated with a rhyolite dome complex [Halsor et al., 1988].

R. E. Criss and D. E. Champion (unpublished data, 1982) analyzed several samples of propylitized basalt from the region and found that most had $\delta^{18} \mathrm{O}$ values less than zero, with two samples being -6.6 and -7.5 . The analyses define a low- ${ }^{18} \mathrm{O}$ zone with an extent of approximately $40 \mathrm{~km}^{2}$ (Figure 18). In addition, a sample of comb quartz from the Morning Star vein has $\delta^{18} \mathrm{O}=-3.6$, and granitic wall rock nearby had a whole rock $\delta^{18} \mathrm{O}$ value of +1.3 . Similarly, quartz crystals from a drusy vug at the open pit mine at DeLamar had a $\delta^{18} \mathrm{O}$ value of -0.9 , and two samples of silicified rhyolite from the pit had values of +1.1 and +3.0 , clearly indicative of meteoric hydrothermal activity.

Mercury Deposits. Mercury deposits and occurrences of $U$ and $\mathrm{Li}$ are associated with the McDermitt caldera complex, a 45-km-diameter Miocene collapse structure that straddles the Nevada-Oregon border [Rytuba and Glanzman, 1979]. The caldera is the source of large volumes of rhyolitic and peralkaline ash flow tuffs, and the $\mathrm{Hg}$ deposits occur in tuffaceous sedimentary rocks (caldera fill) near the ring fractures [Rytuba and Glanzman, 1979]. McDermitt is the largest mercury deposit in North America, with an estimated reserve of 300,000 flasks. Cinnabar is the main ore mineral, but other $\mathrm{Hg}$ - and $\mathrm{Sb}$-bearing phases also occur. Gangue minerals include quartz, cristobalite, K-feldspar, zeolites, alunite, kaolinite, and montmorillonite. Potassium feldspar and smectite are the predominant alteration phases in the ore zone; clinoptilolite and mordenite occur farther out, and a

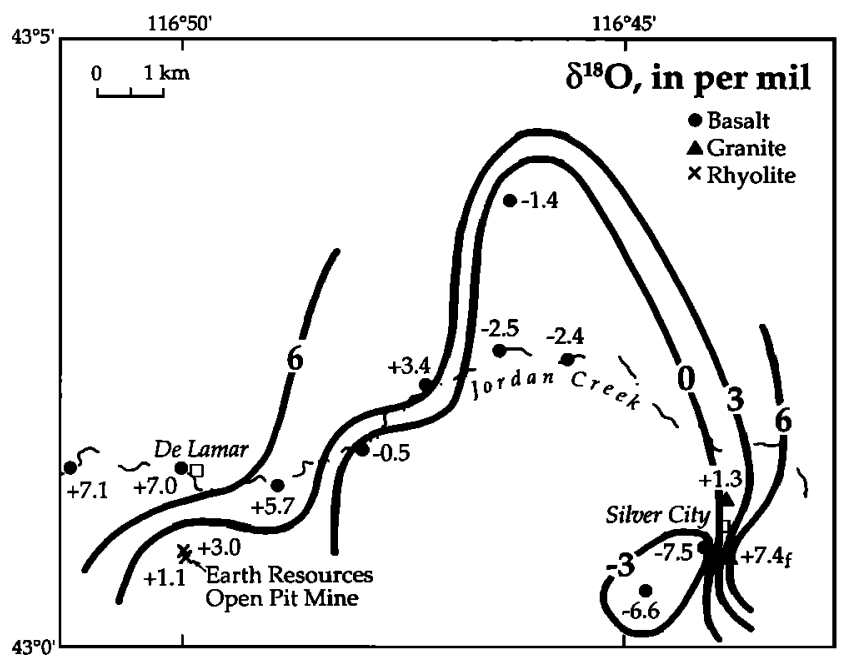

Fig. 18. Contour map of whole rock $\delta^{18} \mathrm{O}$ values of basalt (solid circles), granite (open circles), and thyolite samples (crosses) from the area around Silver City and DeLamar, Idaho. The analyses crudely define a low-18 $\mathrm{O}$ zone, approximately $40 \mathrm{~km}^{2}$ in extent, that was produced by intense circulation of hydrothermal fluids derived from meteoric waters. Important epithermal $\mathrm{Ag}$ and $\mathrm{Au}$ deposits occur near and southwest of Silver City and south of DeLamar (unpublished data of R.E. Criss and D.E. Champion , 1982). narrow glass + clinoptilolite \pm erionite zone extends into unaltered, water-laid vitric tuffs at distance [Rytuba and Glanzman, 1979].

A single $\delta^{18} \mathrm{O}$ analysis of undehydrated opaline material from the Cordero deposit $(+14.4)$, collected a few kilometers southwest of the town of McDermitt, indicates precipitation from fluid with a low $\delta^{18} \mathrm{O}$ value $(<+2.0)$ if temperatures were less than $200^{\circ} \mathrm{C}$, as seems likely. Two samples of andesite collected a few kilometers from the Cordero deposit have "normal" $\delta^{18} \mathrm{O}$ values $(+7.0,+7.9)$.

Mercury also occurs in brecciated opalite in Miocene(?) sedimentary rocks near Weiser, Washington County, Idaho [Ross, 1956]. The deposits are blanketlike and contain cinnabar, pyrite, opal, chalcedony, beidellite, kaolinite, and halloysite [Ross, 1956]. In the most important deposit, the Idaho Almaden Mine, the ore body occurs beneath a "cap rock" of opalized shale [Ross, 1956]. The $\delta^{18} \mathrm{O}$ value of undehydrated opalite $(+14.0)$ from the Idaho Almaden Mine is similar to that at Cordero and thus also suggests formation from a low- ${ }^{18} \mathrm{O}$ fluid. A loose block of chalcedony from the mine had an even lower $\delta^{18} \mathrm{O}$ value of +9.5 , probably indicating precipitation from slightly higher-temperature meteoric hydrothermal fluids. A porous, partially opalitized sample (ash flow tuff?) a few hundred meters from the open pit mine has a whole rock $\delta^{18} \mathrm{O}$ value of +20.8 ; this indicates hydration and silica deposition at low (near-surface) temperatures.

\section{Skarn, Porphyry, and Replacement Deposits}

Eocene molybdenum deposits, Idaho. Most of the Eocene granite plutons strongly associated with meteoric hydrothermal activity within and near the Idaho batholith exhibit anomalously high concentrations of Mo, $\mathrm{U}$, and Be, although these have not yet been exploited commercially [e.g., Kiilsgaard et al., 1970; Bennett, 1980; Toth et al., 1983]. We report here a $\delta^{18} \mathrm{O}$ value of +8.1 for a molybdenitebearing quartz vein with drusy cavities that occurs in leucocratic quartz monzonite (the Tertiary Little Fall Creek stock) at a prospect $21 \mathrm{~km}$ NNE of Ketchum, Idaho. The host rock contains disseminated molybdenite and has a low $\delta^{18} \mathrm{O}$ value of +0.6 ; a small $(20 \mathrm{~cm}$ wide) aplite dike nearby has a value of +5.2. A quartz vein in a barren outcrop a few hundred meters away has a $\delta^{18} \mathrm{O}$ value of +8.0 , and the host quartz monzonite and an aplite dike have $\delta^{18} \mathrm{O}$ values of -0.8 and +1.3 , respectively.

In addition, we obtained a whole rock $\delta^{18} \mathrm{O}$ value of +1.0 for a Tertiary porcellaneous rhyolite dike that contains abundant quartz-molybdenite veinlets in fractures, from the Little Falls Mo prospect in the southern Idaho batholith. The prospect is located within a major northeast-trending dike swarm along the south fork of the Payette River a few kilometers north of Boise Basin (BB, Figure 1). Preliminary fission track age information suggests. an Oligocene age for this dike [Kiilsgaard and Bennett, 1985], although Percious et al. [1967] report Eocene K-Ar ages for several dikes and intrusions in this area, and Rostad [1978] reports an Eocene age for the mineralization.

Ima and Mackay, Idaho. Many of the Tertiary stocks east of the Idaho batholith are associated with significant skarn mineralization. Sheppard et al. [1971] report that coarse quartz and muscovite in a vein cutting quartz monzonite at the Ima mine (I, Figure 1) in the Blue Wing district, Idaho, have 
$\delta^{18} \mathrm{O}$ values of 9.8 and 8.7, respectively. This mineral pair is apparently not in isotopic equilibrium but suggests that temperatures and the fluid $\delta^{18} \mathrm{O}$ value were rather high. However, involvement of (strongly ${ }^{18} \mathrm{O}$-shifted?) meteoric hydrothermal fluid is suggested by a low $\delta \mathrm{D}$ value of -131 for the muscovite. Ima is an important $W$ skam that supposedly is related to an Eocene pluton at depth [e.g., Bennett, 1980].

In addition, we obtained whole rock $\delta^{18} \mathrm{O}$ values of -0.3 for a small, highly chloritized dike, +4.9 for the center of a $10 \mathrm{~m}$ wide, chloritized, granite porphyry dike, and +6.3 for a sample of the Eocene Mackay stock (M, Figure 1) in the Alder Creek mining district, Idaho. This skarn deposit produced more than $\$ 15,000,000$ of copper [Ross, 1941].

Wood River District, Idaho. Lead-silver deposits in the Wood River district (WR, Figure 1) occur as veins or replacement bodies in Paleozoic sedimentary rocks or granitic intrusions, generally within or near strongly sheared zones near intrusive contacts and under the Wood River thrust system [Hall et al., 1978]. A sample of Cretaceous granodiorite from the McCoy mine exhibits a $\delta D$ value of -166 for biotite and $\delta^{18} \mathrm{O}$ values of +11.4 for quartz and +6.0 for potassium feldspar. This low $\delta \mathrm{D}$ value and the large quartz-feldspar ${ }^{18} \mathrm{O}$ fractionation of +5.4 clearly indicate exchange with meteoric hydrothermal fluid [Hall et al., 1978] (compare Figures 4 and 5 ). The $\delta \mathrm{D}$ values of fluid inclusions from ore and gangue minerals from several mines were all between -110 and -120 , again indicative of a meteoric origin for the ore fluid [Hall et al., 1978]. However, the $\delta^{18} \mathrm{O}$ values of quartz gangue $(+16.4)$ and siderite $(+13.3,+14.8)$ from the veins are rather high [Hall et al., 1978], suggesting that the fluid had undergone a considerable ${ }^{18} \mathrm{O}$ shift due to interactions with the finegrained, high- ${ }^{18} \mathrm{O}$ argillite country rocks. Fluid inclusion salinities are also relatively low (3.2-4.8 equivalent wt \% $\mathrm{NaCl}$ ) [Hall et al., 1978]. The age of mineralization has not been determined with certainty but is probably both Late Cretaceous and early Tertiary.

Bluebell, British Columbia. The Bluebell mine, a major producer of lead and zinc, is located a few kilometers east of the Nelson batholith in southern British Columbia (BL, Figure 1). The ore bodies occur as replacements of Cambrian limestone beds and principally comprise pyrrhotite, sphalerite, and galena in a gangue of knebelite, quartz, and carbonate minerals. A detailed stable isotope and fluid inclusion study by Ohmoto and Rye [1970] indicates formation of "period III" vug minerals, which they consider to represent a direct continuation of the period of formation of the massive ores, at high temperatures $\left(320^{\circ}-450^{\circ} \mathrm{C}\right)$ from fluids having salinities of $3-10 \mathrm{wt} \% \mathrm{NaCl}$ equivalent. The $\delta \mathrm{D}$ and $\delta^{18} \mathrm{O}$ values of period III quartz and calcite are indicative of formation from meteoric hydrothermal fluid that had undergone a significant ${ }^{18} \mathrm{O}$ shift at an essentially constant $\delta \mathrm{D}$ value of $-152 \pm 5$; this pattern is virtually identical to that exhibited by many modem geothermal waters (Figure 3). An $\mathrm{Rb}-\mathrm{Sr}$ study of fluid inclusions and mineralized marbles suggests a late Oligocene to mid-Miocene age for the mineralization [Changkakoti $e t$ $a l ., 1988$ ], in agreement with the field observations that the deposit is post metamorphic and that the mineralization cuts lamprophyric dikes of inferred Cenozoic age.

\section{Discussion AND Conclusions}

Large areas of the northwestern United States and southern British Columbia were profoundly affected by Tertiary meteoric hydrothermal systems. Because the pristine meteoric groundwaters of this region had very low $\delta^{18} \mathrm{O}$ and $\delta \mathrm{D}$ values throughout the Tertiary, fluid-rock exchange processes involving such waters caused ${ }^{18} \mathrm{O}$ and $\mathrm{D}$ depletions in the rocks in essentially all the regions where the hydrothermal systems operated. The $\delta^{18} \mathrm{O}$ and $\delta \mathrm{D}$ values of rock and vein materials can be used to calculate the isotopic compositions of the ancient fluids, the temperatures of alteration or precipitation, and the material balance fluid/rock ratios. The isotopic ratios may also be used as a sensitive semiquantitative measure of the "degree" of hydrothermal alteration that facilitates the interpretation of other chemical, physical, and petrographic characteristics of the rocks.

Contour maps of the $\delta^{18} \mathrm{O}$ and $\delta \mathrm{D}$ values of rocks provide a clear-cut means to identify and delimit zones of ancient fluid circulation. Such isotopic mapping techniques have revealed numerous fossil hydrothermal systems in the region of study. These identified systems range in size from a few square kilometers or less to several thousand square kilometers. Small systems typically exhibit simple concentric (bullseye) $\delta^{18} \mathrm{O}$ anomalies and are generally associated with relatively small intrusions and volcanic centers. Large systems typically have annular or elongate $\delta^{18} \mathrm{O}$ patterns and tend to be associated with epizonal batholiths and large calderas. The altered areas are commonly sharply bounded, both laterally and vertically, by zones of steep ${ }^{18} \mathrm{O}$ gradients. However, the $\mathrm{D} / \mathrm{H}$ values of rocks are sensitive to alteration even in low water/rock environments, and anomalously low $\delta D$ values accordingly occur both within and well outboard of the zones of ${ }^{18} \mathrm{O}$ depletion.

Numerous ore deposits are intimately associated with the meteoric hydrothermal systems that have been identified in the region. These tend to be epigenetic veins and stockworks, most commonly of the epithermal type. Most of these deposits are valued for their gold and silver contents, although some have produced substantial $\mathrm{Hg}, \mathrm{Sb}, \mathrm{F}$, and base metals. Many of these deposits, for example, Cordero, Weiser, Republic, and DeLamar, clearly formed in shallow, boiling, hot spring environments. The tops of these systems, where exposed, consist of siliceous sinter that may itself be ore; strong vertical ${ }^{18} \mathrm{O}$ zonation may be present [see Larson and Taylor, 1987].

In addition, several porphyry, skarn, and replacement deposits valued for $\mathrm{Mo}, \mathrm{Cu}, \mathrm{W}, \mathrm{Pb}, \mathrm{Zn}$, and $\mathrm{Ag}$ are also closely associated with the Tertiary meteoric hydrothermal systems. Some deposits, for example Yellow Pine, may have formed when Tertiary meteoric hydrothermal systems concentrated preexisting ore deposits of much lower grade. Multistage relations may also occur in some $\mathrm{Pb}-\mathrm{Zn}$ replacement bodies of the Wood River district, Idaho [Hall et al., 1988].

Meteoric hydrothermal ore deposits in the western United States invariably exhibit all or some combination of a set of distinguishing characteristics: (1) They typically occur within Tertiary volcanic rocks or sediments, or within or near epizonal Tertiary intrusions. (2) The host rocks commonly have low $\delta^{18} \mathrm{O}$ and $\delta \mathrm{D}$ values, with the deposits being particularly concentrated near the zones of very steep $\delta^{18} \mathrm{O}$ gradients that are associated with the isotopically anomalous areas. (3) The host rock and vein $\delta^{18} \mathrm{O}$ values are typically (but not always) low; however, the $\delta^{18} \mathrm{O}$ values depend on the temperature of precipitation and the magnitude of the ${ }^{18} \mathrm{O}$ shift exhibited by the fluid, and the values can therefore be quite high in and around low-temperature deposits (e.g., Weiser $\mathrm{Hg}$ 
deposit). (4) Gangue materials in the meteoric hydrothermal ore deposits almost invariably have low $\delta \mathrm{D}$ values.

Highly mineralized meteoric hydrothermal systems tend to be small, generally 5 to $300 \mathrm{~km}^{2}$ in extent. For example, excepting the Yellow Pine deposit, the combined lode production of the ore deposits associated with all of the enormous low- 180 zones in the Idaho batholith (with a total area of approximately $10,000 \mathrm{~km}^{2}$ ) is smaller than that of the bonanzas associated with the modest-sized $\left(40 \mathrm{~km}^{2}\right)$ altered zone at Silver City and is negligible compared to the production from the small $\left(\ll 100 \mathrm{~km}^{2}\right)$ zone of intense alteration at Butte. This observation may have exploration significance, and it probably is telling us something fundamental about the ore-forming process. This observation could be related to the marked association of ore zones with the zones of high- ${ }^{18} \mathrm{O}$ gradients in wall rocks, which in turn probably reflects an association of ore with zones of steep temperature gradients in the ancient hydrothermal systems. It may be that the temperature gradients associated with small hydrothermal systems and small intrusions are steeper than those associated with larger systems and batholiths. Many of the relatively small, highly mineralized systems such as Yankee Fork and Bohemia may represent the remnants of andesitic stratovolcanoes, as was inferred by Criss et al. [1988] for the $75 \mathrm{~km}^{2}$ low- ${ }^{18} \mathrm{O}$ zone at the Comstock Lode mining district, Nevada.

Numerous additional aspects about the distribution and character of ore deposition in the northwestern United States and southem British Columbia remain to be clarified. Adair [1985; also personal communication, 1988) noted an overall progressive counterclockwise change in the orientation of veins in the region, from an E-W orientation for the earliest Tertiary veins (e.g., Main Stage veins at Butte), to predominantly ENE to NE trending veins for Eocene deposits (e.g., Yankee Fork and many other deposits within the "TransChallis" zone of Kiilsgaard and Bennett, [1985]), to predominantly NNW orientations for Miocene deposits (e.g., Silver City) associated with Basin and Range structures. Many exceptions and complications occur as well (e.g., Republic), but the overall pattern is compelling enough to suggest a relationship of these structures to the evolving regional stress patterns, which in turn are perhaps related to the Cretaceous suturing of accreted terranes to the Precambrian craton in western Idaho [Fleck and Criss, 1985, 1988; Criss and Fleck, 1987].

Workers disagree as to whether the upper mantle or the crust provide the source of the metal in ore deposits. Noble [1970, 1974, 1976] argues that the regional patterns and temporal recurrence of mineralization in given giant provinces, and the association of these metal provinces with volcanic plateaus, requires that the phenomenon of metal occurrence is related to ancient, deep-seated heterogeneous sources. On the other hand, Titley [1987] has shown that the $\mathrm{Ag}: \mathrm{Au}$ ratios of ore deposits in Arizona, independent of age or type, correlate with the geology and Ag:Au ratio of their crustal domains. A crustal source of precious metal in the northwestern United States is consistent with the spatial association of the majority of the ore deposits with medium to large, topographically high regions of negative Bouguer gravity anomalies that mostly correspond to low-density granitic masses [Kutina and Hildenbrand, 1987].

We need to know more about the variation of meteoric waters over time in the northwestern United States and British
Columbia. For example, it is possible that ${ }^{18} \mathrm{O}$-depleted meteoric waters were not as widespread in this region before the Late Cretaceous, owing to warmer temperatures and to the presence [McGookey et al., 1972] of the interior Cretaceous seaway, which extended from the Gulf Coast to the Arctic Ocean. Detailed information about the variation of $\delta \mathrm{D}$ and $\delta^{18} \mathrm{O}$ values of meteoric waters over time in the region may be obtainable from coupled stable isotope and geochronologic studies of meteoric hydrothermal ore deposits. This information would increase understanding of the meteoric hydrothermal systems in this region and would also contribute to present understanding of evolving climatic and paleogeographic conditions.

In addition, we need to know much more about the distribution of $\delta^{18} \mathrm{O}$ and $\delta \mathrm{D}$ values, petrographic features, and chemical and physical properties of hydrothermally-altered regions. Present understanding of the longevity of these systems and about their evolution with time is also severely limited. Fundamental questions about hydrothermal systems and ore-forming processes will remain unresolved until more basic information is obtained.

Acknowledgments. We thank M. Magaritz, D.E. Champion, P.B. Larson, S.M.F. Sheppard, D.H. McIntyre, R.T. Gregory, G.C. Solomon, D. Norton, J.A. Noble, R.S. Lewis, F. Moye, D.H. Adair L.W. Snee, M.G. Sawlan, and R.A. Zielinski for valuable collaboration and discussions. P.B. Larson, D.E. Champion, and F. Moye provided constructive reviews of the manuscript. This research was supported by the U.S. Geological Survey and by NSF grants 8915788 and 88-16413.

\section{REFERENCES}

Adair, D. H., Mineral belts in south-central Idaho, Geol. Soc. Am. Abstr. Programs, 17, 205, 1985.

Anderson, A. L., , Geology and ore deposits of the Lava Creek District, Idaho, Pam. 32, 70 pp., Idaho Bur. of Mines and Geol., Moscow, 1929.

Anderson, A.L., Geology and ore deposits of the Atlanta District, Elmore County, Idaho, Pam. 49, 71 pp., Idaho Bur. of Mines and Geol.,Moscow, 1939.

Anderson, A.L., Geology of the gold bearing lodes of the Rocky Bar District, Pam. 65, 39 pp., Idaho Bur. of Mines and Geol., Moscow, 1943.

Anderson, A.L., Geology and ore deposits of Boise Basin, Idaho, $U$. S. Geol. Surv. Bull., 944C, 119-319, 1947.

Anderson, A.L., Silver-gold deposits of the Yankee Fork district, Custer County, Idaho, Pam. 83, 37 pp., Idaho Bur. of Mines and Geol., Moscow, 1949.

Anderson, A.L., Metallogenic epochs in Idaho, Econ. Geol., 46, 592 $607,1951$.

Armstrong, R.L., W.H. Taubeneck, and P.O. Hales, Rb-Sr and K-Ar geochronometry of Mesozoic granitic rocks and their Sr isotopic composition, Oregon, Washington, and Idaho, Geol. Soc. Am. Bull., 88, 397-411, 1977.

Bennett, E.H., Granitic rocks of Tertiary age in the Idaho batholith and their relation to mineralization, Econ. Geol., 75, 278-288, 1980.

Bergendahl, M.H., Gold, in Mineral and Water Resources of Idaho, US. Geol. Surv. Spec. Rep., 1, 93-101, 1964.

Bird, D.K., R.D. Rogers, and C.E. Manning, Mineralized fracture systems of the Skaergaard intrusion, east Greenland, Greenl. Geosci., 16, 68 pp., 1986.

Brooks, H.C., Quicksilver in Oregon, Bull. Oreg. Dep. Geol. Miner. Ind., 55, 223 pp., 1963.

Buddington, A.F., and E. Callaghan, Dioritic intrusive rocks and contact metamorphism in the Cascade Range in Oregon, Am. J. Sci., 31, 421-449, 1936.

Callaghan, E. and A.F. Buddington, Metalliferous mineral deposits of the Cascade Range in Oregon, U.S. Geol. Surv. Bull., 893, 141 pp., 1938.

Campbell, A., D. Rye, and U. Peterson, A hydrogen and oxygen isotopic study of the San Cristobal mine, Peru: Implications of the 
role of low water to rock ratio for the genesis of wolframite deposits, Econ. Geol., 79, 1818-1832, 1984.

Changkakoti, A., J. Gray, D. Krstic, G.L. Cumming, and R.D. Morton, Determination of radiogenic isotopes $(\mathrm{Rb} / \mathrm{Sr}, \mathrm{Sm} / \mathrm{Nd}$ and $\mathrm{Pb} / \mathrm{Pb}$ ) in fluid inclusion waters: An example from the Bluebell $\mathrm{Pb}$ Zn deposit, British Columbia, Canada, Geochim. Cosmochim. Acta, 52, 961-967, 1988.

Constantopoulos, J., Geology, rare earth element geochemistry, and genesis of fluorite from the Challis $2^{\circ}$ quadrangle, Idaho, Econ. Geol., 83, 626-636, 1988.

Cookro, T.M., and M.L. Silberman, Low-pressure and low-temperature scheelite at the Yellow Pine mining district, Valley County, Idaho, Geol. Soc. Am. Abstr. Programs, 18, 570-571, 1986.

Cookro, T.M., M.L. Silbeman, and B.R. Berger, Gold-tungstenbearing hydrothermal deposits in the Yellow Pine mining district, Idaho, in Bulk Mineable Precious Metal Deposits of the Western United States, edited by R. W. Schafer et al., pp. 577-624, Geological Society of Nevada, Reno, 1988.

Cooper, J.R., Geology of the tungsten, antimony and gold deposits near Stibnite, Idaho, U.S. Geol. Surv. Bull., 969-F, 151-197, 1951 .

Craig, H., Isotopic variations in meteoric waters, Science, 133, 1702 1703, 1961.

Craig, H., The isotope geochemistry of water and carbon in geothermal areas, in Nuclear Geology on Geothermal Areas, edited by E. Tongiorgi, pp. 17-53, Consiglio Nazionale delle Ricerche Laboratorio di Geologia Nucleare Pisa, Spoleto, Italy, 1963.

Craig, H., G. Boato, and D.E. White, Isotopic geochemistry of themal waters: in Conference on Nuclear Processes in Geological Settings, Proc. Natl. Acad. Sci. Res. Counc, Publication 400, 29. 1956.

Criss, R.E., and D.E. Champion, Magnetic properties of granitic rocks from the southem half of the Idaho batholith: Influences of hydrothermal alteration and implications for aeromagnetic interpretation, J. Geophys. Res., 89, 7061-7076, 1984.

Criss, R.E., and R.J. Fleck, Petrogenesis, geochronology, and hydrothermal systems of the nothem Idaho batholith and adjacent areas based on ${ }^{18} \mathrm{O} /{ }^{16} \mathrm{O}, \mathrm{D} / \mathrm{H},{ }^{87_{\mathrm{Sr}}}{ }^{86} \mathrm{Sr}, \mathrm{K}-\mathrm{Ar}$, and ${ }^{40} \mathrm{Ar} /{ }^{39} \mathrm{Ar}$ studies, U.S. Geol. Surv. Prof. Pap., 1436, 95-137, 1987.

Criss, R.E., and A.M. Hofmeister, Application of fluid dynamics principles in tilted permeable media to terrestrial hydrothermal systems, Geophys. Res. Lett., 18, 199-202, 1991.

Criss, R.E., and H.P. Taylor, Jr., An ${ }^{18} \mathrm{O} /{ }^{16} \mathrm{O}$ and D/H study of Tertiary hydrothermal systems in the southem half of the Idaho batholith, Geol. Soc. Am. Bull., 94, 640-663, 1983.

Criss, R.E., and H.P. Taylor, Jr., Meteoric-hydrothemal systems, Rev. Mineral., 16, 373-424, 1986.

Criss, R.E., M.A. Lanphere, and H.P. Taylor, Jr., Effects of regional uplift, deformation, and meteoric-hydrothermal metamorphism on $K$-Ar ages of biotites in the southem half of the Idaho batholith, $J$. Geophys. Res., 87, 7029-7046, 1982.

Criss, R.E., E.B. Ekren, and R.F. Hardyman, Casto ring zone: a 4,500 $\mathbf{k m}^{2}$ fossil hydrothermal system in the Challis volcanic field, central Idaho, Geology, 12, 331-334, 1984.

Criss, R.E., D.E. Champion, and D.H. McIntyre, $\delta^{18} \mathrm{O}$, aeromagnetic and gravity anomalies associated with hydrothermally altered zones in the Yankee Fork mining district, Custer County, Idaho, Econ. Geol., 80, 1277-1296, 1985.

Criss, R.E., R.T. Gregory, and H.P. Taylor, Jr., Kinetic theory of oxygen isotopic exchange between minerals and water, Geochim. Cosmochim. Acta, 51, 1099-1108, 1987.

Criss, R.E., D.E. Champion, and M.F. Horan, Oxygen isotope map of the fossil hydrothermal system in the Comstock Lode mining district, Nevada, U.S. Geol. Surv. Circ., 1035, 11-13, 1988.

Ekren, E.B., D.H. McIntyre, and E.H. Bennett, High-temperature, large-volume, lavalike ash-flow tuffs without calderas in southwestem Idaho, U.S. Geol. Surv. Prof. Pap., 1272, 76 pp., 1984.

Ellis, A.J., and W.A.J. Mahon, Natural hydrothermal systems and experimental hot-water/rock interactions, Geochim. Cosmochim. Acta, 28, 1323-1357, 1964.

Ferry, J., Hydrothermal alteration of Tertiary igneous rocks from the Isle of Skye, norhwest Scotland, I, Gabbroes, Contrib. Mineral. Petrol., 91, 264-282, 1985a.

Ferry, J., Hydrothermal alteration of Tertiary igneous rocks from the Isle of Skye, northwest Scotland, I, Granites, Contrib. Mineral. Petrol., 91, 283-304, 1985 b.
Finch, J.W., Prospecting for gold ores, Pam. 36, 1-33, Idaho Bur. of Mines and Geol., Moscow, 1932.

Fleck, R.J., and R.E. Criss, Strontium and oxygen isotopic variations in Mesozoic and Tertiary plutons of central Idaho, Contrib. Mineral. Petrol., 90, 291-308, 1985.

Fleck, R.J., and R.E. Criss, Location, age, and tectonic significance of the westem Idaho suture zone (WISZ) and its relation to the Idaho batholith, Geol. Soc. Am. Abstr. Programs, 20, 414, 1988.

Garlick, G.D., and S. Epstein, The isotopic composition of oxygen and carbon in hydrothermal minerals at Butte, Montana, Econ. Geol., 61, 1325-1335, 1966.

Gregory R.T., and R.E. Criss, Isotopic exchange in open and closed systems, Rev. Mineral., 16, 91-128, 1986.

Gregory, R.T., R.E. Criss, and H.P. Taylor, Jr., Oxygen isotope exchange kinetics of mineral pairs in closed and open systems: Applications to problems of hydrothermal alteration of igneous rocks and Precambrian iron formations, Chem. Geol., 75, 1-42, 1989.

Gregory, R.T., and H.P. Taylor, Jr., An oxygen isotope profile in a section of Cretpgeous oceanic crust, Samail ophiolite, Oman: Evidence for $\delta^{18} \mathrm{O}$ buffering of the oceans by deep $(>5 \mathrm{~km})$ seawater-hydrothermal circulation at mid-ocean ridges, $J$. Geophys. Res., 86, 2737-2755, 1981.

Hall, W.E., F.S. Fisher, S.W. Hobbs, and R.G. Worl, Syngenetic and epigenetic base- and precious-metal deposits in the Salmon River assemblage of the central Idaho black-shale belt, U.S.A., Geol. Soc. Am. Abstr. Programs, 20, 418, 1988.

Hall, W.E., R.O. Rye, and B.R. Doe, Wood River mining district, Idaho--Intrusion-related lead-silver deposits derived from country rock source, J. Res. U.S. Geol. Surv., 6, 579-592, 1978.

Halsor, S. P., T.J. Bomhorst, M. Beebe, K. Richardson, and W. Strowd, Geology of the DeLamar Silver Mine, Idaho--A volcanic dome complex and genetically associated geothermal system, Econ. Geol., 83, 1159-1169, 1988.

Hildreth, W., R.L. Christiansen, and J.R. O'Neil, Catastrophic isotopic modification of rhyolitic magma at times of caldera subsidence, Yellowstone Plateau volcanic field, J. Geophys. Res., 89, 8339-8369, 1984.

Johnson, S. Y., J.K. Otton, and D.L. Macke, Geology of the Holocene surficial uranium deposit of the north fork of Flodelle Creek, northeastern Washington, Geol. Soc. Am. Bull., 98, 77-85, 1987.

Kerrich, R., and D. Hyndman, Thermal and fluid regimes in the Bitterroot lobe-Sapphire block detachment zone, Montana: Evidence from ${ }^{18} \mathrm{O} /{ }^{16} \mathrm{O}$ and geologic relations, Geol. Soc. Am. Bull., 97, 147-155, 1986.

Kiilsgaard, T.H., and E.H. Bennett, Mineral deposits in the southem part of the Atlanta lobe of the Idaho batholith and their genetic relation to Tertiary intrusive rocks and to faults, U.S. Geol. Surv. Bull., 1658-M, 153-165, 1985.

Kiilsgaard, T.H., V.L. Freeman, and J.S. Coffman, Mineral resources of the Sawtooth Primitive Area, Idaho, U.S. Geol. Surv. Bull., 1319.D. 174 pp., 1970.

Kutina, J., and T.G. Hildenbrand, Ore deposits of the western United States in relation to mass distribution in the crust and mantle, Geol. Soc. Am. Bull., 99, 30-41, 1987.

Larson, P.B. and H.P. Taylor, Jr., An oxygen isotope study of hydrothermal alteration in the Lake City caldera, San Juan Mountains, Colorado, J. Volcanol. Geotherm. Res., 30, 47-82, 1986.

Larson, P.B., and H.P. Taylor, Jr., Solfataric alteration in the San Juan Mountains, Colorado: Oxygen isotope variations in a boiling hydrothermal environment, Econ. Geol., 82, 1019-1036, 1987.

Lewis, R.D., Geochemical Investigations of the Yellow Pine, Idaho and Republic, Washington Mining Districts, Ph.D. thesis, 204 pp., Purdue Univ., West Lafayette, Indiana, 1984.

Lewis, R.D., and Y.N. Shieh, Stable isotopic, mineralogical and wall rock investigation of the Yellow Pine $\mathrm{Au}, \mathrm{W}, \mathrm{Ag}, \mathrm{Sb}, \mathrm{Hg}$ District, Valley County, Idaho, Geol. Soc. Am. Abstr. Programs, 18, 672, 1986.

Lewis, R.S., R.E. Criss, and M.F. Horan, Propylitic alteration in the Idaho batholith and resultant ${ }^{18} \mathrm{O} /{ }^{16} \mathrm{O}$ disequilibrium between coexisting feldspars, Geol. Soc. Am. Abstr. Programs, 21, 106, 1989.

Lindgren, W., and H. Bancroft, Republic District, U.S. Geol. Surv. Bull., 550, 133-166, 1914.

Lipman, P.W., Geologic map of the Lake City caldera area, westem 
San Juan Mountains, southwestem Colorado, scale 1:48,000. US. Geol. Surv. Map, I.962, 1976.

Lund, K., L.W. Snee, and K.V. Evans, Age and genesis of precious metal deposits, Buffalo Hump district, central Idaho: Implications for depth of formation of quartz veins, Econ. Geol., 81, 990-996, 1986.

Magaritz, M., and H.P. Taylor, Jr., ${ }^{18} \mathrm{O} /{ }^{16} \mathrm{O}$ and $\mathrm{D} / \mathrm{H}$ studies along a $500 \mathrm{~km}$ traverse across the Coast Range batholith and its country rocks, central British Columbia, Can. J. Earth Sci., 13, 15141536, 1976.

Magaritz, M., and H.P. Taylor, Jr., Oxygen 18/oxygen 16 and D/H studies of plutonic granitic and metamorphic rocks across the Cordilleran batholiths of southem British Columbia, J. Geophys. Res., 91, 2193-2217, 1986.

Manning, C.E., and D.K. Bird, Hydrothermal clinopyroxenes of the Skaergaard intrusion, Contrib. Mineral. Petrol., 92, 437-447. 1986.

McGookey, D.P., J.D. Haun, L.A. Hale, H.G. Goodell, D.G. McKibbin, J.R. Weimer, and G.R. Wulf, Cretaceous System, in Geologic Atlas of the Rocky Mountain Region, edited by W.M. Mallory, pp. 190-228, Rocky Mountain Association of Geologists, Denver, Colo., 1972.

McIntyre, D.H., S.W. Hobbs, R.F. Marvin, and H.H. Mehnert, Late Cretaceous and Eocene ages for hydrothermal alteration and mineralization, Bayhorse district and vicinity, Custer County, Idaho, Isochron West, 16, 11-12, 1976.

McIntyre, D.H., E.B. Ekren, and R.F. Hardyman, Stratigraphic and structural framework of the Challis Volcanics in the eastem half of the Challis $1^{\circ} \times 2^{\circ}$ quadrangle, Idaho, Bull. Idaho Bur. of Mines and Geol., 26, 3-22, 1982.

Meyer, C., E.P. Shea, and C.C. Goddard, Ore deposits at Butte, Montana, in Ore Deposits of the United States, 1933-1967, Graton-Sales Volume, edited by J.D. Ridge, pp. 1377-1416, American Institute of Mining, Metallurgical and Petroleum Engineers, New York, 1968.

Miller, F.K., and J.C. Engels, Distribution and trends of discordant ages of the plutonic rocks of northeastem Washington and northem Idaho, Geol. Soc. Am. Bull., 86, 517-528, 1975.

Muessig, S., Geology of the Republic Quadrangle and a part of the Aeneas Quadrangle, Ferry County, Washington, U.S. Geol. Surv. Bull., 1216, 135 pp., 1967.

Noble, J.A., Metal provinces of the westem United States, Geol. Soc. Am. Bull., 81, 1607-1624, 1970.

Noble, J.A., Metal provinces and metal finding in the westem United States, Miner. Deposita, 9, 1-25, 1974.

Noble, J.A., Metallogenic provinces of the cordillera of western North and South America, Miner. Deposita, 11, 219-233, 1976.

Norton, D., Theory of hydrothermal systems, Annu. Rev. Earth Planet. Sci., 12, 155-177, 1984.

Norton, D., and J. Knight, Transport phenomena in hydrothermal systems: Cooling plutons, Am. J. Sci., 277, 937-981, 1977.

Norton, D., and H.P. Taylor, Jr., Quantitative simulation of the hydrothermal systems of crystallizing magmas on the basis of transport theory and oxygen isotope data: An analysis of the Skaergaard intrusion, J. Petrol., 20, 421-486, 1979.

Norton, D., H.P. Taylor, Ir., and D.K. Bird, The geometry and hightemperture brittle deformation of the Skaergaard intrusion, $J$. Geophys. Res., 89, 10,178-10,192, 1984.

Ohmoto, H. and R.O. Rye, The Bluebell mine, British Columbia, I, Mineralogy, paragenesis, fluid inclusions, and the isotopes of hydrogen, oxygen, and carbon, Econ. Geol., 65, 417-437, 1970.

O'Neil, J.R., and M.L. Silberman, Stable isotope relations in epithermal Au-Ag deposits, Econ. Geol., 69, 902-909, 1974.

Pearson, R.C., and J.D. Obradovich, Eocene rocks in northeast Washington- radiometric ages and correlation, U.S. Geol. Surv. Bull., 1433, 41 pp., 1977.

Percious, J.K., P.E. Damon, and H.J. Olson, Radiometric dating of Idaho batholith porphyryes, Annu. Prog. Rep., 000-689-76, Appendix A-X, U.S. At. Energy Comm., Washington, D.C., 1967.

Piper, A.M., and F.B. Laney, Geology and metalliferous resources of the region about Silver City, Idaho, Bull. Idaho Bur. Mines Geol., 11, 165 pp., 1926.

Ross, C.P., Ore deposits in Tertiary lava in the Salmon River Mountains, Idaho, Pam. 25, 21 pp., Idaho Bur. of Mines and Geol., Moscow, 1927.

Ross, C.P., Mesozoic and Tertiary granitic rocks in Idaho, J. Geology, $36,673-693,1928$.
Ross, C.P., A classification of the lode deposits of south-central Idaho, Econ. Geol., 26, 169-185, 1931.

Ross, C.P., Geology and ore deposits of the Casto quadrangle, Idaho, U.S. Geol. Surv. Bull., 854, 135 pp., 1934.

Ross, C.P., The metal and coal mining districts of Idaho with notes on the nonmetallic mineral resources of the state, Pam. 57, 263 pp., Idaho Bur. of Mines and Geol., Moscow, 1941.

Ross, C.P., Quicksilver deposits near Weiser, Washington County, Idaho, U.S. Geol. Surv. Bull., 1042-D, 79-104, 1956.

Rostad, O.H., K-Ar dates for mineralization in the White ClondCannivan porphyry molybdenum belt of Idaho and Montana- A discussion, Econ. Geol., 73, 1366-1368, 1978.

Rytuba, J.J., and R.K. Glanzman, Relation of mercury, uranium, and lithium deposits to the McDermitt caldera complex, NevadaOregon, Nev. Bur. of Mines Rep., 33, 109-117, 1979.

Rytuba, J.J., Volcanism, extensional tectonics, and epithermal mineralization in the northem Basin and Range province, California, Nevada, Oregon, and Idaho, U.S. Geol. Surv. Circ., 1035, 59-61, 1988.

Sawlan, M.G., K. Russell, and B. Hart, Gold mineralization and rhyolitic volcanism at the Crone Hill and Quartz Butte deposits, Quartz Mountain district, Oregon, in Geology and Ore Deposits of the Great Basin, Geological Society of Nevada, Reno, in press.

Sheppard, S.M.F., and H.P. Taylor, Jr., Hydrogen and oxygen isotope evidence for the origins of water in the Boulder batholith and the Butte ore deposits, Montana, Econ. Geol., 69, 926-946, 1974.

Sheppard, S.M.F., R.L. Nielsen, and H.P. Taylor, Jr., Oxygen and hydrogen isotope ratios of clay minerals from porphyry copper deposits, Econ. Geol., 64, 755-777, 1969.

Sheppard, S.M.F., R.L. Nielsen, and H.P. Taylor, Jr., Hydrogen and oxygen isotope ratios in minerals from porphyry copper deposits, Econ. Geol., 66, 515-542, 1971.

Silberman, M.L., D.E. White, T.E.C. Keith, and R.D. Dockter, Duration of hydrothermal activity at Steamboat Springs, Nevada, from ages of spatially associated volcanic rocks, U.S. Geol. Surv. Prof. Pap., 458-D, D1-D14, 1979.

Smith, R.L., and H.R. Shaw, Igneous-related geothermal systems, U.S. Geol. Surv. Circ., 726, 58-83, 1973.

Taylor, H.P., Jr., The oxygen isotope geochemistry of igneous rocks, Contrib. Mineral. Petrol., 19, 1-71, 1968.

Taylor, H.P., Jr., Oxygen isotope evidence for large-scale interaction between meteoric ground waters and Tertiary granodiorite intrusions, westem Cascade Range, Oregon, J. Geophys. Res., 76, 7855-7874, 1971.

Taylor, H.P., Jr., $\mathrm{O}^{18} / \mathrm{O}^{16}$ evidence for meteoric-hydrothermal alteration and ore deposition in the Tonopah, Comstock Lode, and Goldfield mining districts, Nevada, Econ. Geol., 68, 747-764, 1973.

Taylor, H.P., Jr., The application of oxygen and hydrogen isotope studies to problems of hydrothermal alteration and ore deposition, Econ. Geol., 69, 843-883, $1974 a$.

Taylor, H.P., Jr., Oxygen and hydrogen isotopic evidence for largescale circulation and interactions between ground waters and igneous intrusions, with particular reference to the San Juan volcanic field, Colorado, in Geochemical Transport and Kinetics, edited by A.W. Hofmann, B.J. Giletti, H.S. Yoder, and R.A. Yund, Carnegie Inst. Washington Publ., 634, 299-324, 1974b.

Taylor, H.P., Jr., Water/rock interactions and the origin of $\mathrm{H}_{2} \mathrm{O}$ in granitic batholiths, J. Geol. Soc. London, 133, 509-558, 1977.

Taylor, H.P., Jr., Comparison of hydrothermal systems in layered gabbros and granites, and the origin of low- 180 magmas, in Magmatic Processes: Physiochemical Principles, edited by Mysen, B.O., Spec. Publ. Geochem. Soc., 1, 337-357, 1987.

Taylor, H.P., Jr. and R.W. Forester, An oxygen and hydrogen isotope study of the Skaergaard intrusion and its country rocks: A description of a $55-\mathrm{m} . y$. old fossil hydrothermal system, $J$. Petrol., 20, 355-419, 1979.

Taylor, H.P., Jr., and M. Magaritz, Oxygen and hydrogen isotope studies of the Cordilleran batholiths of westem North America, in Stable Isotopes in the Earth Sciences, DSIR Bull. 220, edited by B.W. Robinson, pp. 151-173, N. Z. Dep. of Sci. and Ind. Res., Wellington, 1978.

Tilling, R.I., M.R. Klepper, and J.D. Obradovich, K-Ar ages and time span of emplacement of the Boulder batholith, Montana, Am. J. Sci, 266, 671-689, 1968.

Titley, S.R., The crustal heritage of silver and gold ratios in Arizona ores. Geol. Soc. Am. Bull., 99, 814-826, 1987. 
Toth, M.I., B.W. Coxe, N.T. Zilka, and M.M. Hamilton, Mineral resource potential of the Selway-Bitterroot Wildemess, Idaho County, Idaho, and Missoula and Ravalli Counties, Montana, scale 1:125,000, U.S. Geol. Surv. Misc. Field Invest. Map, MF 1495 A. 1983.

Umpleby, J.B., Some ore deposits in northwestem Custer County, Idaho, U.S. Geol. Surv. Bull., 539, 104 pp., 1913.

White, D.E., Antimony deposits of a part of the Yellow Pine district, Valley County, Idaho, U.S. Geol. Surv. Bull., 922-I, 247-279, 1940.

White, D.E., Characteristics of geothermal resources, in Geothermal Energy: Resources, Production, Stimulation, edited by P. Kruger and C. Otte, pp. 69-94, Stanford University Press, Stanford, Califomia, 1973.

White, D.E., L.J.P. Muffler, and A.H. Truesdell, Vapor-dominated hydrothermal systems compared with hot water systems, Econ. Geol., 66, 75-97, 1971.

Zielinski, R.A., S.Y. Johnson, and J.K. Otton, Geologic controls on the formation of a surficial uranium deposit, northeastem Washington, Geol. Soc. Am. Abstr. Programs, 21, 163, 1989.

Zimmerman, B.S., and P.B. Larson, Epithermal gold-mineralization on Indian Head Mountain, Washington County, Idaho, Geol. Soc. Am. Abstr. Programs, 21, 163, 1989.

R. E. Criss, Department of Geology, University of Califomia, Davis,CA 95616.

R. J. Fleck, U.S. Geological Survey, MS 937, 345 Middlefield Road, Menlo Park, CA 94025

H. P. Taylor, Jr., Division of Geological and Planetary Sciences, Califomia Institute of Technology, Pasadena, CA 91125.

Received January 11, 1991 accepted February 27, 1991. 